\title{
O DIREITO FUNDAMENTAL À OBJEÇÃO DE CONSICIÊNCIA NAS ATIVIDADES DE ENSINO QUE UTILIZEM ANIMAIS*
}

\author{
Maira Luciane dos Santos Rodrigues** \\ Rogério Santos Rammê***
}

\section{RESUMO}

A pesquisa teve como objetivo o estudo do instituto da objeção de consciência quando invocado em face de atividades de ensino que utilizem animais. Definido seu conceito, o qual consiste na recusa do cumprimento de norma legal, caso essa norma viole as convicções morais do indivíduo, estabeleceu-se a distinção entre o primeiro instituto e a desobediência civil, que é o ato de desobedecer a lei com intuito de mudança política ou legal. Na legislação estão previstas expressamente duas hipóteses de cabimento, dentre as quais não consta hipótese no tocante às atividades de ensino que utilizem animais. Contudo a doutrina majoritária aduz a possibilidade do alargamento dessas hipóteses, uma vez tratar-se de rol exemplificativo. 0 estudo é qualitativo de revisão bibliográfica. A utilização de animais, conforme já exposto, é permitida pela legislação vigente, entretanto suscita análise de questões éticas e morais, inclusive, a dos

* Artigo apresentado ao Curso de Bacharelado em Direito do Centro Universitário Metodista - IPA, como requisito parcial para obtenção do Grau de Bacharel em Direito.

** Acadêmica do Curso de Bacharelado em Direito do Centro Universitário Metodista - IPA.

*** Doutor em Direito Público pela PUCRS. Mestre em Direito Ambiental pela UCS. Docente do Curso de Direito e Coordenador do Projeto de Extensão Direito dos Animais do Centro Universitário Metodista IPA. Membro da Comissão de Direito Ambiental da OAB/RS. 
animais. Observa-se que a questão ética e moral vem sendo utilizada como substrato para a oposição da objeção de consciência nesses casos. O estudo das decisões judiciais, nesse sentido, identificou parco acervo sobre o tema. Por fim, concluiu-se que o instituto, apesar de ter o condão de tutelar de forma efetiva a liberdade de consciência do indivíduo que objeta por razões morais e éticas o uso de animais em experimentos nas atividades de ensino, ainda carece de uma reflexão mais apurada por parte não só da sociedade, mas dos próprios julgadores, sob pena de relegar um direito fundamental que é pautado na dignidade do ser humano.

Palavras-chave: Direito fundamental. Objeção de consciência. Escusa de uso de animais em atividades práticas de estudo. Senciência e ética.

\section{THE FUNDAMENTAL RIGHT TO OBJECTIVE CONSIDER- ATION IN TEACHING ACTIVITIES THAT USE ANIMALS}

\section{ABSTRACT}

This research aimed at studying the institute of consciousness objection when invoked in the face of activities of education that use animals. Defining their meaning, which consists of the refusal to comply with legal norm, if the norm violates the individual's moral convictions, distinguish between the first institute and civil disobedience, which is the act of disobeying a law for the political or legal. Two provisions are expressly provided for in the legislation, among which there is no hypothesis regarding the activities of teaching that use animals. However, the majority doctrine adds the possibility of extending these hypotheses, once it is an exemplary role. The study is qualitative of bibliographic review. The usage of animals, as explained, is permitted by current legislation, but raises the analysis of ethical and moral issues, including that of animals. It is observed that the ethical and moral question has been used as a substrate for the opposition of consciousness objection in these cases. The study of judicial decisions, in this sense, identified a small collection on the subject. Finally, it was concluded that the institute, despite having the power to effectively protect the freedom of conscience of the individual who objects for moral and ethical reasons the use of animals in experiments in teaching, still requires a more refined reflection not only of society, but also of the judges themselves, under penalty of relegating a fundamental right that is based on the dignity of the human being.

Keywords: Fundamental right. Consciousness objection. Refusal to use animals in practical study activities. Sentience and ethics. 


\section{INTRODUÇÃO}

A estrutura da presente pesquisa desenvolve-se inicialmente pelo estudo da oposição de objeção de consciência ao uso de animais em experimentos científicos no âmbito da educação. Tendo como problema de pesquisa o seguinte questionamento: 0 direito fundamental à objeção de consciência é aplicável às atividades de ensino que utilizem animais?

A questão central deste estudo visa perquirir se a tutela a esse direito é extensiva a uma hipótese que não esteja expressa e se é de fato oponível a essas atividades. A partir disso será delineado seu conceito e a distinção da desobediência civil, analisando, para tanto, as hipóteses previstas na legislação e às referidas na doutrina, bem como a possibilidade de aplicação da objeção de consciência em casos de utilização de animais nas práticas de ensino com a identificação do regramento legal e das demais questões relacionadas a métodos alternativos.

Serão estudadas as práticas de experimentos que utilizam animais em atividades de ensino, assim como analisados os fundamentos éticos que alicerçam a objeção de consciência e estão relacionados aos animais. A seguir será feita a análise de casos concretos de oposição de objeção de consciência no Brasil.

Trata-se de pesquisa qualitativa ${ }^{1}$ de revisão bibliográfica, com consulta à doutrina, legislação e decisões judiciais.

Hoje, com a indiscutível supremacia da Constituição Federal e a proteção por ela conferida aos direitos fundamentais, se mostra imperioso destacar a importância das liberdades, notadamente a

\footnotetext{
"A pesquisa qualitativa preocupa-se com aspectos da realidade que não podem ser quantificados, centrando-se na compreensão e explicação da dinâmica das relações sociais. Ela trabalha com o universo de significados, motivos, aspirações, crenças, valores e atitudes, o que corresponde a um espaço mais profundo das relações, dos processos e dos fenômenos que não podem ser reduzidos à operacionalização de variáveis". Métodos de pesquisa / [organizado por] Tatiana Engel Gerhardt e Denise Tolfo Silveira; coordenado pela Universidade Aberta do Brasil - UAB/UFRGS e pelo Curso de Graduação Tecnológica - Planejamento e Gestão para o Desenvolvimento Rural da SEAD/UFRGS. Porto Alegre: Editora da UFRGS, 2009, p. 32.
} 
liberdade de pensamento e de crença. Nesse rol de direitos, não taxativo ${ }^{2}$, será estudado mais especificamente o direito à objeção de consciência, que vem adquirindo grande destaque, à medida que as pessoas tomam ciência do seu exercício.

Buscando socorro na história brasileira, verificou-se que a Constituição Política do Império do Brazil (sic) previa em seu artigo 5ํ que a religião do Império seria a Católica Apostólica Romana e que todas as outras religiões seriam permitidas desde que em cultos domésticos ou particulares, em casas para isso destinadas. Ressalte-se que única menção referente ao direito de liberdade dizia respeito ao culto e expressão dos pensamentos, todavia com imposição de restrições. ${ }^{3}$

Já a partir da Constituição de 1891, primeira Constituição republicana, se observa maiores garantias quanto às liberdades, sendo que se permitiu o livre exercício do culto publicamente; quanto à possibilidade de alegação por crença religiosa para isentar-se de qualquer ônus que a lei impunha aos cidadãos, aplicava-se a sanção de perda dos direitos políticos. Em prosseguimento, a Constituição de 1934 trouxe um capítulo sobre direitos e garantias individuais, em que previa o direito a igualdade e em seu artigo 113, a liberdade de consciência. Embora estivessem previstos tais direitos, sua efetividade não era alcançada. Já a Constituição de 1937 abarcou além dos direitos anteriores, também os direitos sociais. Entretanto, ainda impunha sanção àquele que se recusasse a cumprir lei imposta a todos por questões religiosas, filosóficas ou políticas. ${ }^{4}$

2 Nesse sentido: Art. 5 $[\ldots] \S 2^{\circ}$ Os direitos e garantias expressos nesta Constituição não excluem outros decorrentes do regime e dos princípios por ela adotados, ou dos tratados internacionais em que a República Federativa do Brasil seja parte.

3 BRASIL. Constituição Política do Império do Brazil. Disponível em: <http://www.planalto.gov.br/ccivil_03/Constituicao/Constituicao24.htm> Acesso em: 16 nov. 2018.

4 BRASIL. Constituição dos Estados Unidos do Brasil de 1937. Disponível em: <http://www.planalto.gov.br/ccivil 03/Constituicao/Constituicao37. htm> Acesso em: 16 nov. 2018. 
Com efeito, a Constituição dos Estados Unidos do Brasil de 1946 finalmente trouxe em seu artigo 141, § 8o o direito à escusa de consciência e o cumprimento de obrigação substitutiva. ${ }^{5}$ Desde então, consolidou-se o direito à objeção de consciência, nos termos da Carta da República vigente.

A Constituição Federal de $1988^{6}$ garante em seu artigo 5ํㅜ, II e IV, a liberdade ao exercício de pensamento, de crença, por convicções filosóficas, políticas ou religiosas. Já no inciso VIII, do artigo $5^{\circ}$ e em seu artigo $143, \S 1^{\text {o }}$, do mesmo diploma, prevê uma prestação alternativa àqueles que invocarem tal objeção e comprovarem tal alegação. Assim, além do instituto da objeção de consciência ter proteção constitucional, de forma genérica contida no art. 5ํㅡ, VIII da CF/88 e de forma específica no art. $143, \S 1^{\circ}$, como escusa ao serviço militar, também se dá por lei especial e decisões judiciais e está em consonância com o artigo XVIII da Declaração Universal dos Direitos Humanos de 19487.

A Lei 9.605 de 1998, em seu artigo 32, § 1ํ, impõe sanção a quem realizar experiência dolorosa ou cruel a animal vivo e, neste cenário, no caso de maus-tratos a animais sujeitos à experimentação pedagógica, encontra todos os elementos para a aplicação da objeção de consciência, eis que há métodos alternativos suficientemente capazes de suprir a não utilização dos animais. Assim, também corrobora para a construção desse trabalho a Lei 11.794 de 2008, que regulamenta o uso de animais em experimentos científicos.

Desse modo, esse trabalho pretende definir a abrangência

5 BRASIL. Constituição dos Estados Unidos do Brasil de 1946. Disponível em: <http://www.planalto.gov.br/ccivil_03/Constituicao/Constituicao46. htm> Acesso em: 16 nov. 2018.

6 BRASIL. Constituição da República Federativa do Brasil de 1988. Disponível em:< http://www.planalto.gov.br/ccivil_03/constituicao/constituicaocompilado.htm> Acesso em: 18 nov. 2018.

7 DECLARAÇÃO UNIVERSAL DOS DIREITOS HUMANOS. Assembleia Geral das Nações Unidas em Paris. 10 dez. 1948. Disponível em: https://nacoesunidas.org/direitoshumanos/declaracao/ Acesso em: 16 nov. 2018. 
do direito de objeção de consciência no que se refere ao uso de animais no ensino, identificando seu tratamento pela legislação vigente e o atual entendimento doutrinário sobre o tema.

A narrativa constrói-se da seguinte forma: inicialmente analisa-se o fundamento do instituto, que é pautado na dignidade da pessoa humana. Na sequência a pesquisa volta-se para a diferenciação da objeção de consciência em relação à desobediência civil, apresentando as hipóteses de cabimento de sua oposição e a partir daí abordam-se as práticas de utilização de animais em estudos didático-científicos. Em prosseguimento, faz-se um estudo da regulamentação legal acerca de atividades que utilizem animais em experimentos. A seguir estudam-se os argumentos éticos relacionados à utilização de animais no ensino, buscando uma justificação para tais práticas. Por fim, analisam-se casos concretos de oposição de objeção de consciência e a efetividade da tutela ao direito fundamental do indivíduo.

\section{O DIREITO FUNDAMENTAL À OBJEÇÃO DE CONSCIÊNCIA}

A dignidade da pessoa humana e os direitos fundamentais do homem têm legitimada sua proteção com o surgimento do Estado constitucional no final do século XVIII. Essa fase histórica inicial surge por ideias religiosas e filosóficas que foram influenciadoras diretas do pensamento jusnaturalista de que o homem, pelo fato de existir, é titular de direitos naturais e inalienáveis, passando pelo pensamento de Santo Tomás de Aquino com sua concepção cristã de igualdade entre os homens perante Deus e da existência de duas ordens, uma pelo direito natural e outra pelo direito positivo e tendo seu ápice de desenvolvimento nos séculos XVII e XVIII por meio das teorias contratualistas. ${ }^{8}$

8 SARLET, Ingo Wolfgang. A Eficácia dos Direitos Fundamentais: uma teoria geral dos direitos fundamentais na perspectiva constitucional. $11 \mathrm{ed}$. rev. e atual. Porto Alegre: Livraria do Advogado, 2012, p. 38, 39. 
Segundo Rodrigo Cesar Rabello Pinho, os "direitos fundamentais são considerados indispensáveis à pessoa humana, necessários para assegurar a todos uma existência digna, livre e igual". ${ }^{9}$ Também afirma não se tratar de rol exaustivo, admitindo outros direitos espalhados no ordenamento jurídico.

Durante a fase de reconhecimento dos direitos fundamentais são citados os direitos baseados na estratificação social ${ }^{10}$, que não seriam propriamente direitos fundamentais, servindo apenas como ponto de referência para alguns direitos e liberdades clássicos civis. A partir daí, seguiram-se várias declarações, como a inglesa no século XVII, declaração do Povo da Virgínia, de 1776, Declaração dos Direitos do Homem e do Cidadão, em 1789 na França, consagrando, assim, para além de direitos fundamentais, direitos humanos. ${ }^{11}$

A partir dessa abordagem histórica estuda-se a dimensão desses direitos fundamentais, que inicialmente têm um cunho individual pela influência do pensamento liberal. Esses direitos constituem direitos de primeira dimensão e encerram os direitos do indivíduo frente ao Estado, notadamente o direito à vida, à liberdade, à propriedade e à igualdade, tendo sido acrescentadas posteriormente outras liberdades, como a de expressão, a liberdade de imprensa, de manifestação, de reunião, dentre outras. ${ }^{12}$

9 PINHO, Rodrigo César Rebello. Teria Geral da Constituição e direitos fundamentais. 12a ed. vol. 17. São Paulo: Saraiva, 2012, p. 200.

10 Estratificação social é um tipo de particular de diferenciação social que resulta da distribuição hierárquica, sistemática de grupos, estratos ou camadas sociais, em razão de sua posição socioeconômica. Significa que as leis eram diferentes para cada classe social. REGO, Maria Laura Pinheiro. Análise da Concepção Funcionalista da Estratificação Social. Disponível em: <http:// www.repositorio.ufc.br/bitstream/riufc/4569/1/1972_art_MLPRego.pdf> Acesso em: 18 nov. 2018, p. 04.

11 SARLET, Ingo Wolfgang. A Eficácia dos Direitos Fundamentais: uma teoria geral dos direitos fundamentais na perspectiva constitucional. $11 \mathrm{ed}$. rev. e atual. Porto Alegre: Livraria do Advogado, 2012, p. 43-44.

12 São direitos individuais oriundos do pensamento liberal-burguês, surgido no século XVIII, que traduz uma não intervenção do Estado, primando pela autonomia individual em face do poder do Estado. Traduzindo-se em direito de cunho negativo, em que requer uma abstenção do poder público. SARLET, Ingo Wolfgang. A Eficácia dos Direitos Fundamentais: uma teoria geral dos direitos fundamentais na perspectiva constitucional, 11 ed. rev. atual. Porto Alegre: Livraria do Advogado, 2012, p. 47. 
Consoante o já exposto, e nas palavras de Ingo Wolfgang Sarlet, as normas que definem os direitos e garantias fundamentais embasam e informam toda a ordem constitucional, integrando o núcleo essencial da Constituição, verbis:

[...] que a noção de dignidade repousa na autonomia pessoal, isto é, na liberdade que o ser humano possui de, ao menos potencialmente, formatar a sua própria existência e ser, portanto, sujeito de direitos, e já não mais se questiona que a liberdade e os direitos fundamentais inerentes à sua proteção constituem simultaneamente pressuposto e concretização direta da dignidade da pessoa, de tal sorte que nos parece difícil questionar o entendimento de acordo com o qual sem liberdade não haverá dignidade, ou, pelo menos, esta não estará sendo reconhecida e assegurada. ${ }^{13}$

Em complemento, merece transcrição a lição de Luis Roberto Barroso: "A dignidade humana assume sua dimensão transcendental e normativa, e a Constituição já não é apenas o documento maior do direito público, mas o centro de todo o sistema jurídico, irradiando seus valores e conferindo-lhe unicidade". ${ }^{14}$

Segundo José Carlos Buzanello, a objeção de consciência espelha a liberdade de consciência, concretizada em um não fazer motivado por questões religiosas, políticas ou filosóficas. É uma espécie de resistência ao cumprimento de uma norma que fere as convicções morais do indivíduo que as alega objetivando um tratamento alternativo. Sendo um direito individual, ou seja, subjetivo, e por isso de pouca ou nenhuma publicidade. ${ }^{15}$

13 SARLET, Ingo Wolfgang. Dignidade da pessoa humana e direitos fundamentais na Constituição Federal de 1988. $8^{\text {a }}$ ed. rev. atual. e ampl. Porto Alegre: Livraria do Advogado Editora, 2010, p. 87, 98.

BARROSO, Luis Roberto. Curso de Direito Constitucional Contemporâneo: os conceitos fundamentais e a construção do novo modelo. 2 ed. Rio de Janeiro: Editora Saraiva, 2010, p. 78.

BUZANELLO, José Carlos. Objeção de consciência: uma questão constitucional. Revista de Informação Legislativa, v. 38, n. 152, 2001. Disponível em: <https://www2.senado.leg.br/bdsf/bitstream/handle/id/730/r152-13. pdf? sequence $=4$ Acesso em: 14 out. 2018, p. 174. 
A referida liberdade de consciência é um direito que está inserido no conjunto de direitos estabelecidos por determinada comunidade política e organizada, com o objetivo de satisfazer ideais ligados à dignidade da pessoa humana ${ }^{16}$. Para José Afonso da Silva, "esses direitos reconhecem autonomia aos particulares, garantindo iniciativa e independência aos indivíduos diante dos demais membros da sociedade política e do próprio Estado"17.

Em semelhante entendimento, Luis Roberto Barroso afirma: "A dignidade da pessoa humana, como atualmente compreendida, se assenta sobre o pressuposto de que cada ser humano possui valor intrínseco e desfruta de uma posição especial no universo"18 e a liberdade de manifestar a sua religião ou convicções, individual ou coletivamente, não pode sofrer outras restrições senão as que, previstas em lei, forem necessárias à segurança pública, à proteção da ordem, da saúde e moral públicas, ou à proteção dos direitos e liberdades de outrem ${ }^{19}$.

Nesse sentido, a objeção de consciência, direito aqui estudado, sendo um direito individual, não se confunde com a desobediência civil, como será verificado a seguir, sendo importante estabelecer a distinção entre esses dois institutos, que embora guardem semelhanças, são distintos.

16 BERNARDES, Juliano Taveira; FERREIRA, Olavo Augusto Vianna Alves. Direito Constitucional - TOMO II - Direito Constitucional Positivo. Coordenação Leonardo de Medeiros Garcia. 5a ed. rev. ampl. e atual. Editora JUSPODVIM, p. 33.

17 SILVA, José Afonso da. Curso de Direito Constitucional Positivo. 25a ed. rev. atual. nos termos da Reforma Constitucional. São Paulo: Editora Malheiros, 2005, p. 191.

18 BARROSO, Luis Roberto. A dignidade da pessoa humana no direito constitucional contemporâneo: a construção de um conceito jurídico à luz da jurisprudência mundial / Luis Roberto Barroso; tradução Humberto Laport de Mello - 3 reimpressão. - Belo Horizonte: Fórum, 2014, p. 15.

19 MELLO, Cleyson de Moraes. Direitos Fundamentais e Dignidade da Pessoa Humana / Cleyson de Moraes Mello, Thiago Moreira. - Rio de Janeiro: Freitas Bastos, 2015. Disponível em: https://bv4.digitalpages.com. $\mathrm{br} /$ ?term =cleyson $\% 2520$ moraes $\% 2520 \mathrm{de} \% 2520$ mello $\&$ searchpage $=1 \&$ filtro=todos $\&$ from $=$ busca $\&$ page $=235 \&$ section $=0 \# /$ edicao $/ 37882$ Acesso em: 02 out. 2018, p. 207. 
Assim, prossegue-se com tal diferenciação, eis que parte da doutrina costuma referir-se a ambos como iguais. Contudo, há que se estabelecer claramente o que cada instituto tutela. Dando continuidade, faz-se necessária a apresentação das hipóteses de cabimento do direito à objeção de consciência, demonstrando, em casos práticos, o entendimento e os argumentos nas decisões já julgadas.

\subsection{DIFERENCIANDO A OBJEÇÃO DE CONSCIÊNCIA DA DESO- BEDIÊNCIA CIVIL}

Objeção de consciência é a recusa de cumprimento de uma prescrição legal, caso essa prescrição fira suas convicções religiosas, ideológicas ou morais, substituindo-a por uma prestação alternativa.

Para José Afonso da Silva a escusa de consciência deriva do direito individual de liberdade de consciência, o qual o indivíduo tem o direito de escusa a prestar determinada imposição legal que contrarie suas convicções religiosas ou filosóficas, mas a lei poderá impor prestação alternativa compatível com suas convicções. ${ }^{20}$

A objeção de consciência se traduz em ato invocado por motivos de consciência, o qual geralmente não gera conflito com interesses de outros indivíduos, pois o que se busca não é a revogação de uma norma vigente, mas tão somente se libertar de tê-la de cumprir pelo fato de que naquele caso específico é uma norma injusta. Tampouco se deseja que isso se torne público, tanto que pode ser dirimido ainda na esfera administrativa. ${ }^{21}$

20 SILVA, José Afonso da. Curso de Direito Constitucional Positivo. 25a ed. rev. atual. nos termos da Reforma Constitucional. São Paulo: Editora Malheiros, 2005, p. 242.

21 GREFF, André Luiz Carvalho; GARABINI, Vânia Maria Basílio. Desobediência Civil e objeção de consciência: distinções. Revista da Faculdade de Direito da UFRGS. Porto Alegre, n. 36, vol. esp. 2017. Disponível em: < $\underline{\mathrm{http}: / / w w w .}$ seer.ufrgs.br/index.php/revfacdir/article/view/69927/44457> Acesso em: 02 set. 2018, p. 177. 
0 primeiro texto abordando o tema da desobediência civil foi escrito por Thoreau em 1849, tendo ele sido preso por se negar a pagar impostos. Ele entendia que o fim dado ao dinheiro arrecadado pelo pagamento do imposto era injusto, pois seria utilizado para a guerra que o governo travava contra o México e manutenção da escravidão que existia, escrevendo assim no início de sua obra:

Será que o cidadão deve, ainda que um momento e em grau mínimo, abrir mão de sua consciência em prol do legislador? Nesse caso, porque cada homem dispõe de uma consciência? Penso que devemos ser primeiro homens, e só depois súditos. Não é desejável cultivar tanto respeito pela lei quanto pelo que é direito. A única obrigação que tenho direito de assumir é a de fazer em qualquer tempo o que julgo ser correto. ${ }^{22}$

Certo é que para o autor não há distinção clara entre o que é objeção de consciência e o que é desobediência civil, portanto, embora tenha suscitado a discussão em torno do tema, é um dos autores que não diferencia claramente os dois institutos.

Para Paula López Zamora ambos os institutos apresentam pontos de encontro, mas possuem características próprias. A autora elenca as diferenças, primeiramente nos sujeitos, eis que na desobediência civil as razões estão ligadas a um interesse coletivo e na objeção de consciência se perfaz por razões da consciência individual. A segunda diferença é a motivação, uma vez que a objeção de consciência se baseia em aspectos morais e éticos e a desobediência civil em questões políticas; ressalvado o fato de que, em última análise, ambos os institutos são reduzidos a um fundamento moral comum. ${ }^{23}$

22 THOREAU, Henry David. A desobediência civil. Tradução de José Geraldo Couto. Editora Companhia das Letras, 2012, p. 06.

23 ZAMORA, Paula López. Análisis comparativo entre La desobediencia civil y La objeción de conciencia. Disponível em: <https://revistas.ucm.es/ index.php/ANDH/article/viewFile/ANDH0202110317A/20968> Acesso em: 02 set. 2018, p. 323-326. 
A terceira diferença é a vocação, em que a objeção de consciência poderá deixar de ser um ato de desobediência ao direito e institucionalizar-se juridicamente, enquanto que a desobediência civil sempre será um ato de desobediência ao direito e não terá a possibilidade de institucionalizar-se. A quarta diferença é a manifestação, vez que a desobediência civil almeja que seus atos tenham repercussão na sociedade, consequentemente de forma pública, permitindo sua execução de forma direta e indireta e como último recurso. Ao contrário, a objeção de consciência não precisa de divulgação de seu ato. Sua execução admite somente a forma direta, sob pena de perder seu significado e motivação, não sendo necessário o esgotamento de outros recursos. ${ }^{24}$

Como o mais estudado elemento diferenciador, porém não último, a autora supra referida menciona a finalidade dos institutos. Na desobediência civil os indivíduos executam seus atos com uma razão coletiva por uma norma ser injusta e buscar-se sua alteração, desse modo, ultrapassando sua esfera individual. Já na objeção de consciência busca-se um objetivo privado e que a norma considerada injusta para si seja afastada. Além disso, cumpre mencionar a atitude frente à penalização pela conduta, em que o objetor de consciência tenta evitar o castigo, inclusive emigrando, vez que o desobediente civil aceita a pena imposta, demonstrando respeito pelo direito e conformidade para com o Estado. ${ }^{25}$

Logo, a objeção de consciência ampara a recusa de cumprimento de dever legal no âmbito individual, enquanto que a desobediência civil é ato público que contraria a lei, porém visa

24 ZAMORA, Paula López. Análisis comparativo entre La desobediencia civil y La objeción de conciencia. Disponível em: < https://revistas.ucm.es/ index.php/ANDH/article/viewFile/ANDH0202110317A/20968> Acesso em: 02 set. 2018, p. 326-329.

25 ZAMORA, Paula López. Análisis comparativo entre La desobediencia civil y La objeción de conciencia. Disponível em: <https://revistas.ucm.es/ index.php/ANDH/article/viewFile/ANDH0202110317A/20968> Acesso em: 02 set. 2018, pág. 330-334. 
uma mudança política e legal, refletindo uma noção comunitária de justiça.

Analisando de forma mais aprofundada verifica-se que a objeção de consciência e a desobediência civil se fundamentam igualmente por motivos de índole subjetiva. Entretanto, observa-se que guardam suas diferenças. Para deixar mais claro, ao opor a objeção de consciência percebe-se o caráter individual, por motivos de consciência, que não afeta os direitos de outros indivíduos e não é publicizada. No que concerne à desobediência civil, trata-se de desobedecer à lei com o objetivo de mudança política ou legal, ou seja, a recusa no cumprimento de uma lei pelo indivíduo objetiva chamar a atenção da sociedade para uma necessária mudança na legislação pelo fato dela ferir princípios éticos ou políticos.

Para Norberto Bobbio, parte-se do princípio que:

[...] é dever fundamental de cada pessoa obrigada a um ordenamento jurídico obedecer às leis. A desobediência civil é uma forma particular de desobediência, na medida em que é executada com o fim imediato de mostrar publicamente a injustiça da lei e com fim mediato de induzir o legislador a mudá-la. ${ }^{26}$

A desobediência civil é um desobedecer à lei quando se entende que esta é injusta, e esse ato é organizado e pacífico, com o objetivo de transformar essa lei para que acompanhe a transformação da sociedade ou restauração do estado anterior, e não tem influência religiosa.

26 Dicionário de Política / Norberto Bobbio, Nicola Matteuci e Gianfranco Pasquino; tradução Carmen C. Varriale... [et. Al.]; coordenação da tradução João Ferreira; revisão geral João Ferreira e Luís Guerreiro Pinto Cascais. 5a ed. - Brasília: Editora Universidade de Brasília: São Paulo: Imprensa Oficial do Estado de São Paulo, 2000, pág. 335. 
Desse modo, é essencial não confundir ambos os institutos, pois como se verá ao longo do trabalho, o objetivo aqui é analisar a possibilidade de reconhecer o direito a objeção de consciência em atividades de ensino que utilizem animais de uma forma dolorosa ou cruel para o animal, ou seja, um direito individual fundamental, invocado para assegurar a liberdade de consciência, preservando os valores do indivíduo, sua visão de mundo e sua dignidade como ser humano. E o que se pretende não é uma alteração das normas vigentes, mas apenas o não cumprimento de uma norma por questões pessoais, de cunho ideológico ou filosófico, pautado em questões ligadas à ética ${ }^{27}$ animal e aos direitos animais.

A par de sua conceituação, a seguir serão analisadas as hipóteses em que é possível invocar a objeção de consciência, levando em consideração as hipóteses previstas na legislação e as referidas pela doutrina, bem como a possibilidade de oposição em casos de atividades que utilizem animais em experimentos no ensino.

\subsection{HIPÓTESES DE CABIMENTO DO USO DA OBJEÇÃO DE CONSCIÊNCIA NO ORDENAMENTO JURÍDICO BRASILEIRO}

As hipóteses de cabimento da objeção de consciência, de forma geral, podem ser opostas por questões religiosas, para re-

27 Para efeitos desse trabalho será utilizado o conceito de ética a partir do entendimento do autor e filósofo Peter Singer, qual seja: “A [...] afirmação sobre a ética cuja veracidade pretendo negar neste primeiro capítulo é aquela segundo a qual a ética é relativa ou subjetiva. [...] Se vou defender a minha conduta em bases éticas, não posso mostrar apenas os benefícios que ela me traz. Devo reportar-me a um público maior. [...] A ética se fundamenta num ponto de vista universal, o que não significa que um juízo ético particular deva ser universalmente aplicável. Significa, isso sim, que, ao emitirmos juízos éticos, extrapolamos as nossas preferências e aversões. [...] Ao admitir que os juízos éticos devem ser formados a partir de um ponto de vista universal, estou aceitando que os meus próprios interesses, simplesmente por serem meus interesses, não podem contar mais que os interesses de uma outra pessoa. Para aprofundar o conceito ver: SINGER, Peter. Ética Prática; tradução Jefferson Luiz Camargo. 3 a ed. São Paulo: Martins Fontes, 2002, p. 09-23. 
cusa de prestação do serviço militar, ao exercício da profissão, ao tratamento sanitário obrigatório e tratamento médico, à obrigação de doação de órgãos, ao aborto, ao trabalho no sábado e de consciência eleitoral. Verifica-se que há oito hipóteses de cabimento citadas pelo autor José Carlos Buzanello ${ }^{28}$, contudo fazendo uma interpretação sistemática do ordenamento podemos inferir que se trata de um rol exemplificativo, de modo que é possível ter reconhecidas novas hipóteses.

Fazendo uma análise mais apurada, apresentam-se a seguir as referidas hipóteses de cabimento de oposição de objeção de consciência:

a) por motivo religioso: se consubstancia pela dispensa de trabalho ou exercício de ato cívico em razão de alguma crença religiosa que impossibilite tais práticas em determinados dias e horários. ${ }^{29}$

b) recusa ao serviço militar: garante uma prestação alternativa a quem se recuse, decorrente de crença religiosa ou de convicção filosófica ou política, conforme determina o artigo $143, \S 1$ o da $\mathrm{CF} / 88$. $^{30}$

c) objeção de consciência ao exercício profissional: como exemplo, se verifica na atividade do advogado, cuja recusa de atuação, por razão de foro íntimo, está am-

28 BUZANELLO, José Carlos. Objeção de consciência: uma questão constitucional. Revista de Informação Legislativa, v. 38, n. 152, 2001. Disponível em: <https://www2.senado.leg.br/bdsf/bitstream/handle/id/730/r152-13. pdf?sequence=4> Acesso em: 14 out. 2018, p. 173-182.

29 BUZANELLO, José Carlos. Objeção de consciência: uma questão constitucional. Revista de Informação Legislativa. Brasília a. 38 n. 152 out/dez 2001. Disponível em: https://www2.senado.leg.br/bdsf/bitstream/handle/ id/730/r152-13.pdf?sequence=4, Acesso em: 14 out. 2018, p. 177.

30 BUZANELLO, José Carlos. Objeção de consciência: uma questão constitucional. Revista de Informação Legislativa. Brasília a. 38 n. 152 out/dez 2001. Disponível em: https://www2.senado.leg.br/bdsf/bitstream/handle/ id/730/r152-13.pdf?sequence=4, Acesso em: 14 out. 2018, p. 177. 
parada no Estatuto da OAB, Lei 8.906 de 1994 em seu artigo $33 .^{31}$

d) tratamento sanitário obrigatório e tratamento médico: há uma limitação da liberdade individual diante de uma questão coletiva para tratamento de alguma enfermidade. 0 Estado deve proteger a saúde coletiva e, em contrapartida, não pode prejudicar um terceiro. 0 autor cita como exemplo o caso de o médico não poder impor tratamento a quem não queira receber, pois o paciente tem o direito de recusar tratamento se isso ferir suas convicções. ${ }^{32}$

e) obrigação de doação de órgãos: é regulamentada pela Lei 9.434/97 e do Decreto 9.175/2017, que declara todos doadores potenciais, contudo, garante a possibilidade de o indivíduo declarar sua vontade de não doar, fazendo constar de sua carteira de identidade ou carteira de habilitação. ${ }^{33}$

f) aborto: essa objeção é invocada pelo profissional que se recusa em executar o ato, por razões morais e mesmo religiosas, não caracterizando discriminação. Contudo, deve ser observado que há casos em que há a necessidade do aborto, quando se apresenta risco para a vida da mãe. Em uma situação que não tenha outra forma de

31 BUZANELLO, José Carlos. Objeção de consciência: uma questão constitucional. Revista de Informação Legislativa. Brasília a. 38 n. 152 out/dez 2001. Disponível em: https://www2.senado.leg.br/bdsf/bitstream/handle/ id/730/r152-13.pdf?sequence=4, Acesso em: 14 out. 2018, p. 177.

32 BUZANELLO, José Carlos. Objeção de consciência: uma questão constitucional. Revista de Informação Legislativa. Brasília a. 38 n. 152 out/dez 2001. Disponível em: https://www2.senado.leg.br/bdsf/bitstream/handle/ id/730/r152-13.pdf?sequence=4, Acesso em: 14 out. 2018, p. 177-178.

33 BUZANELLO, José Carlos. Objeção de consciência: uma questão constitucional. Revista de Informação Legislativa. Brasília a. 38 n. 152 out/dez 2001. Disponível em: https://www2.senado.leg.br/bdsf/bitstream/handle/ id/730/r152-13.pdf?sequence=4, Acesso em: 14 out. 2018, p. 178. 
salvar a vida da gestante, a recusa na execução do aborto se configura em omissão de socorro, conforme o disposto nos artigos 128, I e 135 do Código Penal Brasileiro. ${ }^{34}$

g) trabalho ou outras atividades aos sábados: por questões religiosas, tratando-se dos Adventistas do Sétimo Dia e, embora não exista legislação tutelando outro dia senão o domingo como dia de descanso, a OIT reconhece o sábado como dia festivo. ${ }^{35}$

h) objeção de consciência eleitoral: comporta as justificativas de quando o cidadão não quiser participar da produção do poder político e de quando o quiser, mesmo não havendo candidatos compatíveis com suas convicções políticas. ${ }^{36}$

No presente trabalho estuda-se o instituto da objeção de consciência quando oposto às atividades de ensino que utilizem animas em experimentos didático-científicos. Existe a possibilidade de se invocar o instituto para não participar de atividade que exponha animais à crueldade desnecessária, causando-lhes dor, sofrimento e até mesmo a morte. Essa forma de objeção diz respeito ao indivíduo que se recusa a participar de uma aula de vivissecção ${ }^{37}$, e o que se busca é uma prestação alternativa a

34 BUZANELLO, José Carlos. Objeção de consciência: uma questão constitucional. Revista de Informação Legislativa. Brasília a. 38 n. 152 out/dez 2001. Disponível em: https://www2.senado.leg.br/bdsf/bitstream/handle/ id/730/r152-13.pdf?sequence=4, Acesso em: 14 out. 2018, p. 178.

35 BUZANELLO, José Carlos. Objeção de consciência: uma questão constitucional. Revista de Informação Legislativa. Brasília a. 38 n. 152 out/dez 2001. Disponível em: https://www2.senado.leg.br/bdsf/bitstream/handle/ id/730/r152-13.pdf?sequence=4, Acesso em: 14 out. 2018, p. 178-179.

36 BUZANELLO, José Carlos. Objeção de consciência: uma questão constitucional. Revista de Informação Legislativa. Brasília a. 38 n. 152 out/dez 2001. Disponível em: https://www2.senado.leg.br/bdsf/bitstream/handle/ id/730/r152-13.pdf?sequence=4, Acesso em: 14 out. 2018, p. 179.

37 O termo vivissecção (do latim vivu "vivo" + seccione "secção"), classicamente faz referência à dissecação (abertura por incisão) de animais vivos, anestesiados ou não, para estudo da natureza fisiológica. LIMA, João Epifânio Regis. Vozes do Silêncio: cultura científica: ideologia e alienação no discurso sobre vivissecção. 1aㅡ ed. São Paulo: Instituto Nina Rosa, 2008, p. 20. 
essa prática. Esse comportamento não fere a liberdade de outras pessoas, pois se concentra na esfera individual do opositor.

Desse modo, a objeção de consciência "tem que ser acomodada às necessidades e aos direitos de outras pessoas", pois "o direito de um não autoriza a discriminação de outro". ${ }^{38}$

A partir dessa análise, estuda-se o sacrifício animal nas práticas de ensino e a regulamentação acerca dessas atividades, bem como sua efetividade, frente aos interesses das instituições e dos órgãos competentes para o controle e fiscalização de experimentos. A seguir, ainda serão abordadas questões éticas quanto a essas práticas, trazendo reflexões de filósofos e biólogos acerca do tema.

\section{OBJETANDO O SACRIFÍCIO ANIMAL NAS PRÁTICAS DE ENSINO}

A objeção de consciência, para além do que já foi abordado até o momento, vagarosamente vem sendo oposta quando se trata do uso de animais em experimentos didático-científicos nas atividades de ensino. Isso se deve, como já referido, por razões de foro íntimo ou convicções morais que não permitem a aceitação de determinadas práticas.

Não obstante a tutela constitucional conferida aos animais, que lhes garante alguns direitos, pode-se observar que eles estão inseridos na esfera ambiental, o que denota que a referida proteção tem como escopo principal a proteção do meio ambiente. Evidencia-se também que toda legislação infraconstitucional que trata da proteção dos animais se mostra inócua, notadamente, em razão da falta de estrutura no que diz respeito à fiscalização e à punição.

Essa precariedade de efetivação das normas de proteção aos animais também fundamenta a oposição da objeção de consciên-

38 DINIZ, Débora. Objeção de Consciência. Disponível em: < http://www.anis. org.br/objecao-de-consciencia/> Acesso em: 02 set. 2018. 
cia, eis que não fosse a sua falta de efetividade, tal oposição não se faria necessária.

Para além da legislação existente, se mostra imperiosa a discussão sobre a utilização de animais nas práticas de ensino, já que a justificativa utilizada para essa conduta é o aprendizado prático dos estudantes; trata-se de uma imposição sem nenhum tipo de reflexão sobre o impacto dessas atividades, tanto para o aluno como para os animais. Nesse sentido, Anamaria Feijó: “0 argumento da busca do bem ao ser humano normalmente impera sobre o argumento da sensibilidade animal". ${ }^{39}$

A par disso, no presente tópico pretende-se desenvolver a análise da legislação referente à proteção animal, à prática de experimentos didático-científicos, bem como os argumentos éticos que lastreiam a oposição de objeção de consciência e a análise de julgados em que foi invocado tal instituto.

\subsection{ASPECTOS LEGAIS E REGULAMENTARES DA UTILIZAÇÃO DE ANIMAIS NO ENSINO}

É certo que vivemos numa sociedade antropocêntrica, onde o homem se coloca no centro da vida e do mundo, explorando os animais de forma incessante e cruel. Nas atividades de ensino, embora tenha havido progressos no que diz respeito à utilização de animais, é sabido que ainda há muito caminho a percorrer para uma efetivação mais ampla da tutela dos animais, de modo a abolir o sofrimento infligido pela sua objetificação.

A constitucionalização da proteção animal na Constituição Federal de 1988 coube à Liga de Prevenção da Crueldade contra o Animal - LPCA, juntamente com a União dos Defensores da Terra - OIKOS e à Associação Protetora de Animais São Francisco de Assis - APASFA, que promoveram um abaixo-assinado com

39 FEIJÓ, Anamaria Gonçalves dos Santos. Utilização de animais na investigação e docência: uma reflexão ética necessária. Porto Alegre: EDIPUCRS, 2005, p. 73. 
11.000 assinaturas e tiveram papel fundamental na inclusão do artigo 225, § 1ํㅡ, VII na Constituição. Embora, quando elaborada, a Constituição tenha avançado diante do clamor da sociedade, no sentido de estabelecer uma consideração moral aos animais, se pautou na ideia antropocêntrica, relacionando a proteção animal à funcionalidade de cada espécie e nos interesses sociais e econômicos do homem, tanto no que se refere à pesquisa e experimentação, quanto ao que diz respeito à agricultura e alimentação. ${ }^{40}$

Contudo, como refere Tagore Trajano, "o direito animal propõe uma dilatação dos fundamentos éticos aos animais, reconhecendo o direito inerente a todos os seres vivos no patamar constitucional". ${ }^{41}$

Mesmo antes da Constituição Federal de 1988, havia legislação infraconstitucional voltada a regular a utilização de animais em experimentos. A Lei 6.638/1979 ${ }^{42}$, que foi revogada pela Lei $11.794 / 2008^{43}$, era uma lei que, aliás, não se restringia a regular a utilização de animais em experimentos, mas autorizava em todo o território nacional a vivissecção de animais de acordo com as normas nela contidas. Ademais, não especificava a formação do responsável técnico e nem o local para a prática dessas atividades.

40 DIAS, Edna Cardozo. A defesa dos animais e as conquistas legislativas do movimento de proteção animal no Brasil. Revista Brasileira de Direito Animal. Vol. 2. N. 2. Jan/jun, 2007, p. 160.

41 TRAJAnO, Tagore. Teoria da Constituição: Direito Animal e Pós-Humanismo (Constitutional Theory: Animal Law and Post-Humanism). 2013. Disponível em: <http://www.egov.ufsc.br/portal/sites/default/ files/2013_10_11683_11731.pdf> Acesso em: 02 set. 2018, p. 27.

42 BRASIL. Lei no 6.638, de 08 de maio de 1979. Lex: Estabelece normas para a prática didático-científica da vivissecção de animais e determina outras providências. Revogada pela Lei 11.794, de 08 de outubro de 2008. Disponível em: <http://www.planalto.gov.br/ccivil_03/_ato2007-2010/2008/ lei/l11794.htm> Acesso em: 11 nov. 2018.

43 BRASIL. Lei no 11.794 de 08 de outubro de 2008. Lex: Regulamenta o inciso VII do $\S 1^{\circ}$ do artigo 225 da Constituição Federal, estabelecendo procedimentos para o uso científico de animais; revoga a Lei no 6.638, de 08 de maio de 1979; e dá outras providências. Disponível em: <http://www. planalto.gov.br/ccivil_03/_ato2007-2010/2008/lei/l11794.htm> Acesso em: 11 nov. 2018. 
A referida lei também previa que o animal que não fosse sacrificado, deveria ser encaminhado para pessoas ou entidades que por ele se responsabilizassem. Aos infratores dessa lei incidiria o disposto no artigo 64 da Lei de Contravenções Penais ${ }^{44}$, à interdição do local e cancelamento do registro do biotério ou centro de pesquisa, no caso de reincidência. Apesar de não permitir a utilização de animais sem uso de anestesia, sem supervisão de técnico especializado e em estabelecimentos frequentados por menores de idade, era ineficaz pela falta de fiscalização.

Contudo, a Lei 11.794/2008, conhecida como Lei Arouca, que revogou a Lei 6.638/79, promoveu várias alterações, especificando os locais onde podem ser utilizados os animais, delimitando quais são as atividades consideradas de pesquisa, a qual órgão compete o controle dessas atividades, a criação de comitês de ética nas instituições para controlar as atividades de pesquisa com animais, bem como a indicação de competência do Ministério da Ciência e Tecnologia para licenciar as atividades destinadas à criação de animais ao ensino e à pesquisa. A referida lei também trata das penalidades impostas às instituições em caso de transgressão às normas estabelecidas em seu texto.

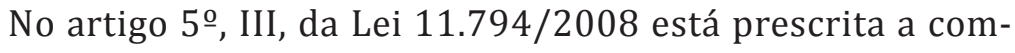
petência para zelar pelo cumprimento das normas de utilização humanitária dos animais, avaliar a introdução de técnicas alternativas para a substituição desses animais, dentre outras normas, deixando a critério dos comitês de ética para o uso de animais (CEUAS) a regulamentação interna e específica de cada instituição. Isso permite que os cientistas ou professores decidam sobre a necessidade de utilização de animais, quais as espécies e a quantidade para determinado experimento, tornando essa lei, assim como a anterior, pouco efetiva.

44 BRASIL. Decreto-Lei no 3.688, de 03 de outubro de 1941. Lei das Contravenções Penais. Disponível em: < http://www.planalto.gov.br/ccivil 03/ Decreto-Lei/Del3688.htm> Acesso em: 11 nov. 2018. 
Ainda, em seu art. $14, \S 3^{\circ}$, a Lei Arouca determina que: "sempre que possível, as práticas de ensino deverão ser fotografadas, filmadas ou gravadas, de forma a permitir sua reprodução para ilustração de práticas futuras, evitando-se a repetição desnecessária de procedimentos didáticos com animais", visando evitar a utilização desnecessária de novos animais nesses procedimentos.

De modo a exercer controle e fiscalização, o Conselho Nacional de Controle de Experimentação Animal - CONCEA, órgão integrante do Ministério da Ciência e Tecnologia, criado pela Lei $11.794 / 2008$, tem caráter normativo, consultivo, deliberativo e recursal e normatiza o uso de animais em ensino ou pesquisa científica ${ }^{45}$. Também lhe compete cadastrar as Instituições para criação ou utilização de animais, estabelecendo normas e cuidados com os animais, normas técnicas para instalação e funcionamento de centros de criação, biotérios e laboratórios de experimentação.

Já as diretrizes brasileiras para o cuidado e a utilização de animais ${ }^{46}$ em atividades de ensino ou de pesquisa científica do CONCEA, em seu capítulo $V$, especifica as responsabilidades das Instituições e de seus comitês de ética no uso e manutenção dos animais utilizados, determinando a criação de mecanismos que permitam ao órgão que rege a Instituição ou seu representante garantir a conformidade com a legislação e com essas diretrizes.

Da legislação pesquisada, percebe-se certa sensibilidade no tocante ao tratamento dispensado aos animais e no que se refere

45 BRASIL. Ministério da Ciência, Tecnologia, Inovações e Comunicações. Conselho Nacional de Controle de Experimentação Animal - CONCEA. Disponível em: <https://www.mctic.gov.br/mctic/opencms/institucional/ concea/paginas/concea.html> Acesso em: 02 set. 2018.

46 BRASIL. MINISTÉRIO DA CIÊNCIA E TECNOLOGIA E INOVAÇÃO, CONCEA. Diretriz brasileira para o cuidado e a utilização de animais para fins científicos e didáticos - DBCA. Brasília/DF. 2013, p. 10. Disponível em: <http://pages.cnpem.br/ceua/wp-content/uploads/sites/56/2015/06/ DBCA.pdf> Acesso em: 10 nov. 2018. 
à regulamentação quanto à sua utilização em pesquisas didáticocientíficas. Entretanto, é visível a inefetividade dos instrumentos de controle, fiscalização e consequente responsabilização pela não observância de tais normas e regras, uma vez que os órgãos que devem controlar e fiscalizar, na verdade tem o maior interesse nas práticas de experimentação. Já os CEUAS que são constituídos dentro das instituições, se por um lado pretendem demonstrar à sociedade que há um controle e fiscalização interna, por outro, também tem interesse na divulgação e publicação das pesquisas feitas pela sua instituição. Não é tarefa difícil concluir que o que se apresenta é uma legislação meramente simbólica.

Historicamente, observa-se que a experimentação animal vem de longa data, com justificativa no desenvolvimento tecnológico e científico e desde as primeiras experiências, se difundiu cada vez mais, mesmo com a legislação construída para regular esse campo e do esforço dispensado pelas organizações de proteção animal.

Considerando alguns avanços conquistados que repercutiram na preocupação com o sofrimento animal, pode-se citar um princípio denominado de 3Rs, apresentado em livro publicado em 1959, por William Russel e Rex Burch, na Inglaterra, que se baseia num tratamento mais humano dispensado aos animais. 0 referido princípio é baseado em uma concepção de bem estar animal e não da abolição na sua utilização. ${ }^{47}$ Ele trata de prescrições na utilização dos animais que consistem em substituição (replacement) dos animais por métodos alternativos ${ }^{48}$ que utilizem outros materiais

47 RUSSEL, William M. S.; BURCH, Rex L. The Principles of Humane Experimental Technique. Johns Hopkins Bloomberg School of Public Health. Special Edition. Disponível em: <http://altweb.jhsph.edu/pubs/books/humane exp/ het-toc > Acesso em: 10 nov. 2018.

48 Entende-se por métodos alternativos, programas computadorizados, realidade virtual, vídeos interativos ou demonstrativos, manequins específicos, entre outros que estão atualmente sempre sendo propostos. FEIJó, Anamaria Gonçalves dos Santos. Utilização de animais na investigação e docência: uma reflexão ética necessária. Porto Alegre: EDIPUCRS, 2005, p. 80. 
não sencientes, podendo ocorrer a substituição total ou parcial desses animais; a redução (reduction) do número de animais investigados nos laboratórios e o refinamento (refinement) das técnicas empregadas, com objetivo de diminuição da severidade e, consequentemente, do sofrimento animal, bem como diminuição do medo, da dor, da angústia e desconforto dos animais. ${ }^{49}$

A partir desse conceito nasceram novas ideias com o objetivo de atenuar a forma com que os animais são utilizados e, consequentemente, surgiu uma abordagem alternativa à prática utilizada em experimentos e estudos, amparada na ideia de substituição ou redução do uso ou sofrimento animal, que foi proposta nos anos 80, como revisão da proposta dos 3Rs. Todavia, ela trouxe uma confusão quanto ao significado e a ideia do princípio dos 3Rs, que buscava o bem estar animal, acabou se tornando uma solução alternativa. ${ }^{50}$

De outro lado, mesmo que a Lei Arouca não tenha alcançado uma diminuição ou substituição significativa no uso de animais, seja por desconhecimento de que há métodos alternativos por parte dos próprios educadores, seja por resistência às mudanças desses modelos de experimentação, por questões econômicas em implementar novos métodos de estudos nas aulas e mesmo pela falta de especificidade das legislações quanto ao conceito dos seus textos, avança-se ainda que lentamente para uma proteção mais ampla e efetiva dos animais não-humanos. ${ }^{51}$

A Lei 9.605/98, em seu artigo $32, \S 1 \stackrel{0}{ }$, determina que:

${ }^{49}$ ALBUQUERQUE, Lia do Valle C. de. A ética e a experimentação animal à luz do direito brasileiro e da União Européia. Revista Brasileira de Direito Animal. V. 10, n. 18, jan-abr. 2015, p. 96 e 97.

50 SILVA, Rodrigo Muniz da. Experimentação Animal: Objeção ao Sacrifício do Outro. 2010. 265 f. Dissertação (Mestrado) - Faculdade de Medicina da Universidade de Porto. Porto, 2010.

51 FEIJÓ, Anamaria Gonçalves dos Santos. Utilização de animais na investigação e docência: uma reflexão ética necessária. Porto Alegre: EDIPUCRS, 2005, p. 93 e 95. 
Art. 32. Praticar ato de abuso, maus tratos, ferir ou mutilar animais silvestres, domésticos ou domesticados, nativos ou exóticos:

Pena - detenção, de três meses a um ano, e multa. $\S 1^{\text {o }}$ - Incorre nas mesmas penas quem realiza experiência dolorosa ou cruel em animal vivo, ainda que para fins didáticos ou científicos, quando existirem recursos alternativos. ${ }^{52}$

Nota-se que mesmo a referida lei de crimes ambientais, ao passo que impõe sanção e considera crime os atos de abusar, maltratar, ferir e mutilar os animais permite claramente essas práticas, desde que não haja recursos alternativos. Logo, a tutela a tais direitos carece também de efetividade, uma vez que a própria lei flexibiliza a proteção conferida.

No que concerne à questão legal envolvendo essa relação do homem com os animais, compartilha-se o pensamento de Fernanda Medeiros e Letícia Albuquerque:

O grande desafio do direito contemporâneo é conseguir abraçar os anseios de uma sociedade que está vivenciando mutações do seu modo de agir e de pensar em uma velocidade impressionante. Hodiernamente, (re) pensar a questão dos animais não-humanos e sua posição no ordenamento jurídico não é mais situação estabelecida em um pequeno nicho e, nessa seara, as provocações por enxergar o Direito de forma diferente é quase um imperativo. ${ }^{53}$

52 BRASIL. Lei no 9.605, de 12 de fevereiro de 1998. Lex: Dispõe sobre as sanções penais e administrativas derivadas de condutas e atividades lesivas ao meio ambiente, e dá outras providências. Disponível em: <http://www. planalto.gov.br/ccivil_03/LEIS/L9605.htm> Acesso em: 11 nov. 2018.

53 MEDEIROS, Fernanda Luiza Fontoura de; ALBUQUERQUE, Letícia. Constituição e animais não-humanos: um impacto no direito contemporâneo. Disponível em: <http://www.publicadireito.com.br/artigos/?cod=1845faa2957cb42b> Acesso em: 11 nov. 2018, n.p. 
Um bom exemplo dessa evolução gradual na proteção dos animais é a recente publicação no Diário Oficial da União, da Resolução no 1.236, de 26 de outubro de 2018, do Conselho Federal de Medicina Veterinária, que estabelece o conceito de crueldade, maus-tratos e abuso contra animais vertebrados. Essa resolução, além de trazer a definição de crueldade, maus-tratos e abuso, também dispõe sobre a conduta de médicos veterinários e zootecnistas e dá outras providências:

Art. 2ํ Para os fins desta Resolução, devem ser consideradas as seguintes definições:

I - animais vertebrados: o conjunto de indivíduos pertencentes ao reino animal, filo dos Cordados, subfilo dos Vertebrados, incluindo indivíduos de quaisquer espécies domésticas, domesticadas ou silvestres, nativas ou exóticas;

II - maus-tratos: qualquer ato, direto ou indireto, comissivo ou omissivo, que intencionalmente ou por negligência, imperícia ou imprudência provoque dor ou sofrimento desnecessários aos animais; III - crueldade: qualquer ato intencional que provoque dor ou sofrimento desnecessários nos animais, bem como intencionalmente impetrar maus tratos continuamente aos animais;

IV - abuso: qualquer ato intencional, comissivo ou omissivo, que implique no uso despropositado, indevido, excessivo, demasiado, incorreto de animais, causando prejuízos de ordem física e/ou psicológica, incluindo os atos caracterizados como abuso sexual; (Grifei)

A Resolução também estabelece os deveres dos médicos veterinários e zootecnistas e a responsabilização pela não observância do disposto na referida Resolução. 0 que chama atenção para o que seria mais um passo em direção à efetiva proteção e tratamento mais humanitário para os animais é que no inciso VIII do artigo $2^{\circ}$ desta resolução, juntamente com o artigo $5^{\circ}$, $\S 1^{\text {o }}$, que tratam 
da eutanásia, abate e depopulação, não consideram maus-tratos desde que sejam seguidas as normas e recomendações técnicas vigentes para essas práticas, e ainda no mesmo artigo $5^{\circ}$, $§ 2^{\circ}$, traz uma exceção quanto ao confinamento por motivos de ensino e pesquisa enquanto estes sistemas forem legalmente permitidos. ${ }^{54}$

Diante da legislação apresentada, surge para muitos indivíduos um conflito de natureza moral, quando seus valores e princípios em prol do respeito à vida animal são afrontados pela legislação vigente e, no que se refere ao objeto da presente pesquisa, pela conduta de professores e pesquisadores que impõem um modelo ultrapassado de estudo e pesquisa; em situações tais, resta a esses indivíduos o direito de se oporem às atividades de ensino propostas por meio da objeção de consciência.

Nina Trícia Disconzi e Adriane Ferrari entendem que apesar da Lei de Crimes Ambientais tipificar como crime as práticas de experimentos no caso de haver métodos substitutivos, a Lei Arouca, não incentiva os pesquisadores a desenvolver métodos alternativos ao uso de animais. Ressalta também que nesse caso não há uma lei que imponha aos estudantes realizar essas práticas de vivissecção e dissecação, não podendo se falar em descumprimento da lei. As universidades se prevalecem de sua autonomia didático-científica garantida pela constituição em seu artigo $207^{55}$, para impor-lhes esse tipo de conduta. Contudo, assim como não há lei que regulamente a objeção de consciência

54 CONSELHO FEDERAL DE MEDICINA VETERINÁRIA. Define e caracteriza crueldade, abuso e maus-tratos contra animais vertebrados, dispõe sobre a conduta de médicos veterinários e zootecnistas e dá outras providências. Resolução no 1.236, de 26 de outubro de 2018. Diário Oficial da União, Brasília, DF, Edição 208, Seção 1. Disponível em: <http://portal.imprensanacional.gov.br/web/guest/materia/-/asset_publisher/Kujrw0TZC2Mb/ content/id/47542721/do1-2018-10-29-resolucao-n-1-236-de-26-de-outubro-de-2018> Acesso em: 11 nov. 2018, p. 133.

55 BRASIL. Constituição da República Federativa do Brasil. Art. 207 - As universidades gozam de autonomia didático-científica, administrativa e de gestão financeira e patrimonial, e obedecerão ao princípio de indissociabilidade entre ensino, pesquisa e extensão. Disponível em: http://www.planalto. gov.br/ccivil 03/Constituicao/Constituicao.htm Acesso em: 05 dez. 2018. 
em universidades, também não há lei que obrigue os alunos a realizar essas práticas. ${ }^{56}$

A seguir busca-se identificar os principais argumentos de cunho ético a amparar a utilização da objeção de consciência por indivíduos contrários à utilização de animais em práticas de ensino que lhes inflijam dor, sofrimento ou mesmo a morte como, por exemplo, a vivissecção.

\subsection{FUNDAMENTOS DA ÉTICA ANIMAL PARA A OBJEÇÃO DE CONSCIÊNCIA NAS PRÁTICAS DE ENSINO}

Segundo Immanuel Kant, ética é a ciência das leis da liberdade, também chamada de filosofia dos costumes. E que deveríamos proceder como se a máxima ${ }^{57}$ de nossa ação devesse ser elevada à lei universal, ou seja, deveríamos agir da mesma forma que gostaríamos que todos agissem. ${ }^{58}$ Ocorre que seu conceito só tem validade para o ser humano, pois entende que os animais não

56 RODRIGUES, Nina Trícia Disconzi; FERRARI, Adriane de Freitas. 0 direito à objeção de consciência à experimentação animal em práticas didáticas.

Revista Brasileira de Direitos Fundamentais \& Justiça. V. 8. N. 26, 2014. Disponível em: http://dfj.emnuvens.com.br/dfj/article/view/227 Acesso em: 05 dez. 2018, p. 180.

57 A máxima é o princípio subjetivo para agir que o próprio sujeito transforma em regra para si (a saber, como ele quer agir). 0 princípio do dever, em contrapartida, é aquilo que a razão lhe ordena absoluta e, portanto, objetivamente (como ele deve agir). KANT, Immanuel. Metafísica dos Costumes. Tradução [primeira parte] Célia Aparecida Martins, tradução [segunda parte] Bruno Nadai, Diego Kosbiau e Monique Hulshof. Petrópolis, RJ: Vozes; Bragança Paulista, SP: Editora Universitária São Francisco, 2013. (Coleção Pensamento Humano). Disponível em: <http://lelivros.love/book/ baixar-livro-fundamentacao-da-metafisica-dos-costumes-immanuel-kant -em-pdf-epub-e-mobi-ou-ler-online/> Acesso em: 20 out. 2018, p. 28.

58 KANT, Immanuel. Metafísica dos Costumes. Tradução [primeira parte] Célia Aparecida Martins, tradução [segunda parte] Bruno Nadai, Diego Kosbiau e Monique Hulshof. Petrópolis, RJ: Vozes; Bragança Paulista, SP: Editora Universitária São Francisco, 2013. (Coleção Pensamento Humano). Disponível em: <http://lelivros.love/book/baixar-livro-fundamentacao-da-metafisicados-costumes-immanuel-kant-em-pdf-epub-e-mobi-ou-ler-online/> Acesso em: 20 out. 2018, p. 28. 
devem ser titulares dessa ética, eis que eles não estão incluídos na comunidade moral, podendo o homem utilizá-los como meio para realização dos seus objetivos.

Para Carlos Naconecy ética se refere a como devemos agir e afirma que a empatia é um elemento básico para atitudes éticas, ou seja, quando tais atitudes tem efeito sobre outros indivíduos. Segundo ele, a ética animal é um ramo da ética ambiental, que está para além dos humanos e que, hoje, é uma ideia melhor aceita pela sociedade. De fato no passado a questão ética se restringia apenas a proibir atos cruéis intencionais contra animais, entretanto percebeu-se que esses atos não eram por crueldade e sim pela utilização normal dos animais, que é aceita pela sociedade. Destaca que o tratamento que dispensamos aos animais é antiético e que eles não são como nós, mas são semelhantes a ponto de poderem ser incluídos na comunidade moral. ${ }^{59}$

Já Tom Regan afirma que os animais são sujeitos-de-uma-vida, tal qual os seres humanos, sendo essa a principal razão para atribuirmos um valor moral a eles; assim, Regan defende que, em sendo os animais sujeitos-de-uma-vida, eles têm direitos assim como nós, humanos. Esclarece que há diversas semelhanças entre os animais e os seres humanos, como a linguagem, comportamento, corpos e sistemas comuns, que permitem estabelecer essas semelhanças e que devemos também tratar os animais com ética. ${ }^{60}$

Nessa linha de raciocínio, Peter Singer defende a igual consideração de interesses na relação entre homens e animais, refutando o especismo ${ }^{61}$. Entende que não pode haver justificação

59 NACONECY, Carlos Michelon. Ética \& animais: um guia de argumentação filosófica. Porto Alegre: Edipucrs, 2006, p. 17-19.

60 REGAN, Tom. Jaulas Vazias: encarando o desafio dos direitos animais; tradução Regina Rheda; revisão técnica Sônia Felipe, Rita Paixão. Porto Alegre: Lugano, 2006, p. 65 a 72.

61 Especismo é prática que privilegia, de forma arbitrária, os interesses de uma determinada espécie biológica em detrimento das demais. Trata-se 
para a experimentação animal em benefício do ser humano, vez que esse entendimento viola o princípio ético da igual consideração de interesses. ${ }^{62}$

0 autor ainda afirma que a ética não é considerada, ou pelo menos não a ética para os animais, quando está em jogo um mercado muito lucrativo para diversas empresas, que engloba desde as empresas que criam animais, as que fabricam armadilhas, jaulas onde esses animais viverão e até mesmo àquelas que fabricam os materiais que serão utilizados nos experimentos. Logo, percebe-se a grande dificuldade e luta para por fim a toda exploração animal. ${ }^{63}$

Cabe aqui destacar um conceito fundamental em ética animal: a senciência animal. Segundo Carlos Naconecy, "para a Ética Animal, em especial, dizer que um animal é senciente equivale a dizer que o animal é (a) capaz de sentir dor (b) desejar que ela acabe." 0 autor reforça sua análise afirmando que o animal senciente "percebe ou está consciente de como se sente, onde está, com quem está e como é tratado".64

A senciência animal, aliás, tem comprovação científica. Nesse

de uma discriminação arbitrária verificável pela ausência de justificativa moral para o referido privilégio de interesses apenas amparado no critério de pertencimento a uma dada espécie biológica. RAMMÊ, Rogério Santos. Especismo e esquizofrenia moral na tutela jurisdicional do crime de maus-tratos a animais: uma mirada jurisprudencial. In: SCHEFFER, Gisele Kronhardt (org). Direito animal e ciências criminais. Porto Alegre: Canal Ciências Criminais, 2018, p. 124.

62 Princípio ético da igual consideração de interesses é um princípio baseado em questões morais, subjetivas, não tendo fundamento em princípios constitucionais. Para Peter Singer esse princípio significa que em nossas deliberações morais, atribuímos o mesmo peso aos interesses semelhantes de todos os que são atingidos por nossos atos, ou seja, um interesse é um interesse, seja lá de quem for esse interesse. SINGER, Peter. Ética Prática. Tradução de Jefferson Luís Camargo. 2a ed. São Paulo: Martins Fontes, 1998, p. 32.

63 SINGER, Peter. Ética prática. Tradução de Jefferson Luís Camargo. 2a ed. São Paulo: Martins Fontes, 1998, p. 65-92.

64 NACONECY, Carlos Michelon. Ética \& animais: um guia de argumentação filosófica. Porto Alegre: Edipucrs, 2006, p. 108. 
sentido, em 07 de julho de 2012, um grupo de especialistas de diversas áreas se reuniu na Universidade de Cambridge, no Reino Unido, para reavaliar os substratos neurobiológicos de animais humanos e não humanos. Todos os especialistas participantes assinaram o documento que declara:

A ausência de um neocórtex não parece impedir que um organismo experimente estados afetivos. Evidências convergentes indicam que os animais não humanos têm os substratos neuroanatômicos, neuroquímicos e neurofisiológicos dos estados conscientes, juntamente com a capacidade de exibir comportamentos intencionais. Consequentemente, o peso da evidência indica que os seres humanos não são únicos em possuir os substratos neurológicos que geram a consciência. Animais não humanos, incluindo todos os mamíferos e aves, e muitas outras criaturas, incluindo polvos, também possuem esses substratos neurológicos. (Tradução livre) ${ }^{65}$

Apenas para que se tenha dimensão da gravidade das barbáries as quais os animais são expostos, o biólogo Thales Tréz, na obra "A Verdadeira Face da Experimentação Animal”66,

65 Texto original em inglês: "The absence of a neocortex does not appear to preclude an organism from experiencing affective states. Convergent evidence indicates that non-human animals have the neuroanatomical, neurochemical, and neurophysiological substrates of conscious states along with the capacity to exhibit intentional behaviors. Consequently, the weight of evidence indicates that humans are not unique in possessing the neurological substrates that generate consciousness. Nonhuman animals, including all mammals and birds, and many other creatures, including octopuses, also possess these neurological substrates." Francis Crick Memorial Conference. Cambridge, UK, july $7^{\text {th }}$ 2012. Declaração de Cambridge sobre Consciência em Animais Humanos e Não Humanos. Disponível em: <fcmconference.org/> Acesso em: 24 out. 2018.

66 GREIF, Sergio; TRÉZ, Thales. A Verdadeira Face da Experimentação Animal. Rio de Janeiro: Sociedade Educacional Fala Bicho, 2000. Disponível em: <http://www.falabicho.org.br/PDF/LivroFalaBicho.pdf> Acesso em: 24 out. 2018 , p. 13. 
descreve em uma de suas obras uma situação em que um cão é anestesiado e tem seu tórax aberto para observação dos movimentos pulmonares e cardíacos, em seguida recebe a injeção de drogas para análise de resultado do procedimento, findando pela injeção de alta dose de anestésico que lhe causará parada cardíaca. A crueldade conferida por tais práticas pode ser verificada no sofrimento de animais indefesos, muitas vezes criados para esse determinado fim, tendo sofrido maus-tratos antes mesmo dos experimentos, por viverem confinados, na maior parte em más condições. Além de todo mal infligido a esses animais, segundo o autor Thales Tréz, os próprios estudantes se tornam vítimas dessas atividades, pois frequentemente têm que abdicar de seus princípios morais em nome da ciência, sofrendo, ao longo do tempo, uma forte dessensibilização na relação com os animais utilizados em atividades e experimentos de ensino. ${ }^{67}$

Segundo afirma Sérgio Greif, a utilização de animais para estudos didático-científicos vem sendo questionada em todo o mundo por diversos profissionais, tanto da área científica, estudantes, pela sociedade civil, tendo como fundamento considerações éticas, psicológicas, ambientais e metodológicas. Defende a substituição dos animais por técnicas mais responsáveis, e apresenta métodos alternativos ao seu uso, elencando alguns exemplos, tais como: aulas didático-expositivas; utilização de modelos e simuladores mecânicos; utilização de simuladores por meio de softwares, de realidade virtual e modelos matemáticos; utilização por métodos ilustrativos com apresentação de fotos e filmagem das aulas; estudo anatômico de animais mortos por causas naturais ou circunstâncias não-experimentais; estudos de campo e observacionais, dentre outros. ${ }^{68}$

Em meio a tantos relatos impactantes relativos a diferentes experimentos realizados com animais, muitos outros podem ser

67 GREIF, Sérgio. Alternativas ao uso de animais vivos na educação pela ciência responsável. São Paulo: Instituto Nina Rosa, 2003, p. 15.

${ }_{68}$ GREIF, Sérgio. Alternativas ao Uso de Animais Vivos na Educação pela Ciência Responsável. São Paulo: Instituto Nina Rosa, 2003, p. 23-32. 
verificados em obras de autores como Peter Singer, Tom Regan, assim como diversos outros autores. Em 1872, Charles Darwin, publicava a obra-prima "A Expressão das Emoções nos Homens e Animais", que veio expor as enormes similaridades emocionais e psicológicas entre humanos e não-humanos. Algumas passagens são bastante elucidativas a esse respeito, senão vejamos:

Quando os animais agonizam de dor, eles geralmente se contorcem terrivelmente, e aqueles que habitualmente usam a voz soltam soluços e uivos penetrantes. Praticamente todos os músculos do corpo são intensamente acionados. Vimos que os sentimentos e a intuição, as várias emoções e faculdades, tais como amor, memória, atenção e curiosidade, imitação, razão, etc. das quais o homem se orgulha, podem ser encontradas em estado incipiente, ou mesmo, por vezes, numa condição bem desenvolvida nos animais. ${ }^{69}$

Aprofundando a análise sobre a questão ética relacionada aos animais, que lhes confere tanto um valor moral, como direitos fundamentais básicos, que são direitos inerentes ao ser humano, a Doutora Sônia Terezinha Felipe corrobora com esse entendimento, ao afirmar que:

Muitos humanos, e todos os animais, por serem inaptos para o gozo pleno da autonomia, encontram-se na mesma condição de vulnerabilidade moral aos atos e decisões de sujeitos conscientes de si e capazes de expropriá-los de sua liberdade. Mas, nem humanos nem animais incapazes de raciocinar de acordo com os padrões considerados humanos, são destituídos de suas liberdades fundamentais. ${ }^{70}$

69 DARWIN, Charles. A Expressão das Emoções no Homem e nos Animais. São Paulo: Companhia das Letras, 2000, p. 73.

70 FELIPE, Sônia Terezinha. Ética e experimentação animal: fundamentos abolicionistas. Florianópolis: Editora da UFSC, 2007, p. 28. 
Diomar Ackel Filho afirma que os animais não são apenas coisas:

\begin{abstract}
Não pode mais ser simplesmente referida como coisa ou bem. É que esses seres, porque providos de vida biológica e outros elementos, incluindo psiquismo ativo, já mereceram do Estado outro status. Não são simplesmente apenas coisas ou meros números. Mas individualidades biopsicológicas, que vêm recebendo o reconhecimento jurídico em todas as partes do mundo. (...) Considerar os animais meras coisas, como desprovidas de vida e sentimentos, afronta a consciência ética da humanidade. Se há pessoas que assim os considere, desprezando seus direitos, a imensa maioria dos habitantes do planeta nutre sentimentos de respeito pelos animais. É daí que verte esse elemento moral, traduzido na justiça do reconhecimento dos seus direitos e da repulsa a todas as formas de crueldade e biocídio. ${ }^{71}$
\end{abstract}

Bianca Pazzini vai além ao afirmar que não basta que os animais deixem de ser considerados como coisas, pois isso não confere respeito às suas individualidades. Afirma que isso é uma simples "solução antropocêntrica à medida que não tira do ser humano a centralidade em tratar os animais deste ou daquele modo", pois ainda permite a exploração mesmo não tratando o animal como coisa. ${ }^{72}$

Desse modo percebe-se a difícil barreira a ser vencida pelos argumentos éticos para alcançar um mínimo de dignidade para os animais, mesmo com os avanços já conquistados para o seu bem estar e tratamento mais humanitário. Entende-se que o tema é tão relevante que enseja discussões acirradas no campo ético

71 ACKEL FILHO, Diomar. Direito dos Animais. São Paulo: Themis, 2001, p. 61-63.

72 PAZZINI, Bianca. Direitos animais e literatura. Rio de Janeiro: Lumen Juris, 2017, p. 94. 
e moral, o que é fundamento suficiente para demonstrar que a violação de consciência alegada por indivíduos que se recusam a causar dor e sofrimento a animais em atividades de ensino possui fundamentação substancial.

Nesse mesmo sentido, Nina Trícia Disconzi e Adriane Ferrari asseveram:

As justificativas para o reconhecimento da objeção de consciência podem ser de diversas ordens, como política, jurídica e moral. Entretanto, estas justificativas devem revestir-se de grau bastante forte embasadas em valores morais, igualando a objeção a um estado de necessidade do indivíduo. Nesse prisma, observa-se que quando a vivissecção ofende as convicções filosóficas ou morais do aluno, ele não deve ser forçado a realizar tais aulas, considerando que a opção de aderir ou não a esta metodologia deve ser assegurada ao estudante, facultando a este, em contrapartida, a realização de trabalhos alternativos. ${ }^{73}$

A partir desse contexto, no próximo tópico estudam-se casos em que foi invocado o direito de objeção de consciência em face de instituições que utilizavam animais em suas atividades de ensino.

\subsection{CASOS CONCRETOS DE OBJEÇÃO DE CONSCIENNCIA NO ÂMBITO DE ATIVIDADES DE ENSINO UTILIZADORAS DE ANIMAIS}

Apesar de ser um instituto frequentemente invocado em razão do serviço militar, do exercício da profissão, entre outros,

73 RODRIGUES, Nina Trícia Disconzi; FERRARI, Adriane de Freitas. O direito à objeção de consciência à experimentação animal em práticas didáticas. Revista Brasileira de Direitos Fundamentais \& Justiça. V. 8. N. 26, 2014. Disponível em: http://dfj.emnuvens.com.br/dfj/article/view/227 Acesso em: 05 dez. 2018, p. 83. 
a objeção de consciência se mostra um possível mecanismo de proteção animal. Mesmo que indiretamente, a objeção de consciência, no caso de atividades de ensino que utilizam animais em experiências didáticas, acaba por tutelar os animais contra crueldade ou mesmo contra a morte, além de assegurar um direito fundamental a todo indivíduo que, por razões de consciência, não concorde com a submissão dos animais a certas práticas educativas que lhe inflijam dor, sofrimento ou morte.

No Brasil, existem alguns casos já julgados pelo Poder Judiciário envolvendo a invocação da objeção de consciência com objetivo de proteger os animais utilizados em atividades de ensino.

A primeira ação, precursora na discussão desse tema, foi movida por Rober Freitas Bachinski, estudante de Biologia, em face da universidade Federal do Rio Grande do Sul - UFRGS, no processo no 2007.71.00.019882-0/RS, que tramitou na 9a Vara Federal Ambiental de Porto Alegre.

Inicialmente o pedido liminar formulado foi acolhido pelo magistrado de primeira instância, fundamentando sua decisão na conduta do autor, por trazer um tema de tal importância à discussão:

A conduta do aluno é elogiável porque busca discutir clara e abertamente uma questão que, embora complexa e polêmica, é muito relevante num curso que propõe trabalhar com seres vivos e compreender seus mecanismos de funcionamento, entre outras questões. ${ }^{74}$

74 BRASIL. 9ạ Vara Federal de Porto Alegre. Lex: Sentença 0066/2007. Róber Freitas Bachinski e Universidade Federal do Rio Grande do Sul. Juiz Candido Alfredo Silva Leal Junior. Porto Alegre, 26 de maio 2008. Disponível em: < https:// www2.trf4.jus.br/trf4/processos/visualizar documento gedpro.php?local=jfrs $\&$ documento $=3312740 \&$ DocComposto $=\&$ Sequencia $=\&$ hash $=5 \mathrm{bba} 4665 \mathrm{e}-$ 7fb831406ec56975cfe58db> Acesso em: 11 nov. 2018. 
A decisão liminar, em apertada síntese, reconheceu os argumentos trazidos pelo autor no que diziam respeito à violação de sua consciência em razão da utilização de animais em experimentos didático-científicos, antecipando os efeitos da tutela para determinar a imediata suspensão da decisão do réu no processo 23078.020775/06-35 (que negou a objeção de consciência ao autor) e de seus efeitos, determinar que o réu providencie junto aos professores responsáveis pelas disciplinas de Bioquímica II e Fisiologia Animal B que elaborem trabalhos alternativos para o autor, substituindo as aulas práticas, tendo esses trabalhos reconhecimento da Universidade e suficientes para validade e fins de aprovação final no curso de bacharelado em Ciências Biológicas, em tempo hábil para a conclusão do curso e em igualdade com os demais estudantes, sob pena de multa; para determinar que a UFRGS apresente, no prazo da contestação, relação das disciplinas do curso de ciências biológicas que usam animais em aulas práticas, a quantidade e a espécie do animal, bem como a justificativa didática para tal uso e comprovação de forma justificada a impossibilidade de oferecer aos alunos recursos alternativos à prática. Todavia, indeferiu o pedido liminar para determinar que a ré suspenda imediatamente o sacrifício de animais ou prática de vivissecção para todas as aulas práticas do Curso de Ciências Biológicas.

A ré, inconformada, interpôs agravo de instrumento ao TRF4, que suspendeu os efeitos da decisão de primeira instância, sob o argumento de não ser razoável a ré dispensar tratamento diferenciado aos alunos que alegarem objeção de consciência, tendo que adaptar o currículo com as convicções pessoais de cada aluno, tornando assim, inviável a instituição de ensino:

ANTECIPAÇÃO DE TUTELA. CURSO DE CIÊNCIAS BIOLÓGICAS. PARTICIPAÇÃO EM AULAS PRÁTICAS COM USO DE ANIMAIS. OBJEÇÃO DE CONSCIÊNCIA. Não é razoável que, no curso de ciências biológicas, deva a Universidade dispensar tratamento diferen- 
ciado aos acadêmicos que possuírem objeção de consciência no curso em que matriculados, a adaptar o currículo de acordo com as convicções pessoais dos alunos, sob pena de inviabilizar a instituição de ensino, sobretudo, quando não há notícias de abuso na utilização de animais para uso acadêmico, apenas e tão-só a obrigação legal do ensino, da pesquisa e formação competente do profissional egresso das classes de universidades como a Agravante.

(TRF4 - AG: 20715 RS 2007.04.00.020715-4, Relator: EDGARD ANTÔNIO LIPPMANN JÚNIOR, Data de Julgamento: 29/08/2007, QUARTA TURMA, Data de Publicação: D.E. 17/09/2007).

Percebe-se que a fundamentação da decisão do Tribunal, ao suspender os efeitos da decisão de antecipação de tutela, em nenhum momento argumentou sobre o direito fundamental, objeto da demanda, a objeção de consciência, ignorando que o que se está a discutir é um direito garantido pela Constituição Federal e que tem sua construção fundada na dignidade da pessoa humana.

Contudo, ainda que o TRF4 tenha suspendido os efeitos da decisão liminar, após a dilação probatória, o juiz ratificou seu entendimento mantendo os fundamentos jurídicos anteriormente exarados na decisão liminar, agora sob a forma de sentença:

É um direito do aluno manter-se fiel às suas crenças e convicções, não praticando condutas que violentem sua consciência nem se vendo privado de suas possibilidades discentes por conta disso; Não parece que o aluno esteja tentando furtar-se à obrigação legal a todos imposta e recusar-se a cumprir prestação alternativa fixada em lei, uma vez que o aluno busca justamente seu direito à prestação alternativa não-discriminatória;

0 aluno não poderia ser discriminado por conduzir-se de acordo com os ditames de suas crenças e de sua consciência, o que acaba ocorrendo quando e reprovado ou tem sua nota diminuída numa disciplina porque se recusou a participar de uma determinada prática que violentaria suas convicções, 
como é o caso de aulas práticas com a utilização de animais mortos especialmente para isso;

0 professor e a instituição de ensino não podem impor aos alunos uma única visão didático-pedagógica, sem respeitar as alternativas disponíveis e viáveis, uma vez que isso afronta os valores constitucionais do pluralismo político, a liberdade do aluno e a diretriz constitucional de que o ensino deve respeitar o pluralismo de ideias e concepções pedagógicas; A objeção de consciência devidamente formalizada pelo aluno não decorre de mero capricho nem é arbitrária, encontrando amparo em diversas posturas sociais e movimentos de defesa de direitos em que indivíduos ou grupos defendem que os animais mereçam respeito enquanto animais e que têm direitos que devem ser protegidos contra a atuação humana desnecessária, inclusive havendo menção na petição inicial a diversos grupos e sites onde são disponibilizados recursos e métodos alternativos às aulas práticas com animais mortos;

A objeção de consciência do autor também encontra amparo constitucional no artigo 225, VI e VII da Constituição da República Federativa do Brasil, que impõe ao Poder Público a promoção de educação ambiental em todos os níveis de ensino (...);

Aquela objeção de consciência também é fruto de uma especial percepção do princípio da dignidade da pessoa humana (art. $1^{\circ}$-III da CF/88), partilhada pelo aluno com diversos outros grupos de pessoas da sociedade, que defendem que os animais não devem ser sacrificados de forma desnecessária, devendo-se sempre buscar os meios menos gravosos quanto a essas práticas de ensino e consumo (...); A questão posta na objeção de consciência é tão relevante que o próprio legislador penal a considerou na edição da Lei Ambiental, instituindo uma figura típica específica no art. $32-\S 1^{\circ}$ da Lei $9.605 / 98 .^{75}$

75 BRASIL. 9a Vara Federal de Porto Alegre. Lex: Sentença 0066/2007. Róber Freitas Bachinski e Universidade Federal do Rio Grande do Sul. Juiz Candido Alfredo Silva Leal Junior. Porto Alegre, 26 de maio 2008. Disponível em: <https:// www2.trf4.jus.br/trf4/processos/visualizar_documento_gedpro.php?local=jfrs $\&$ documento $=3312740 \&$ DocComposto $=\&$ Sequencia $=\&$ hash $=5 \mathrm{bba} 4665 \mathrm{e}-$ 7fb831406ec56975cfe58db> Acesso em: 11 nov. 2018. 
Observa-se, da sentença, que o magistrado julgou procedente a maioria dos pedidos, declarando nula a decisão administrativa que negou o pedido do autor, reconhecendo o direito constitucional do autor a exercer a objeção de consciência, determinando que a instituição disponibilizasse trabalhos alternativos em substituição às aulas práticas e condenando a instituição ré ao pagamento de danos morais suportados pelo autor. Contudo, julgou improcedente o pedido para que fosse proibido o uso de animais nas aulas práticas do Curso de Ciências Biológicas da ré e a concessão do prazo de seis meses para que ela procedesse à substituição do uso de animais por métodos alternativos em todas as disciplinas do Curso de Ciências Biológicas, razão pela qual, julgou parcialmente procedente a ação.

Cabe ressaltar aqui o posicionamento do Ministério Público em parecer promovido nos autos deste processo com algumas considerações:

Um estudante do curso de Ciências Biológicas, como é o caso do autor, não tem apenas o direito constitucional de ver respeitada a sua objeção de consciência, levantada em defesa do meio ambiente/fauna contra prática de experimentos didático-científicos pelo uso de animais, mas até mesmo o dever de fazer valer as exigências constitucionais e legais de defesa do meio ambiente, quando a Instituição de Ensino Superior assim não o fizer; que o entendimento do Ministério Público Federal é no sentido de que a Universidade tem o dever de aceitar o pedido de objeção de consciência formulado pelo autor de oferecer a todos os seus alunos formas alternativas de trabalhos à vivissecção, ainda mais quando se trata de um Curso de Biologia, em que a principal preocupação é a vida; que não se está a discutir sobre a possibilidade ou não de uso de animais para elaboração de teses médicas, que possam salvar vidas, como argumentado em sede de contestação pela UFRGS, mas se está discutindo a objeção de 
consciência de um aluno ante a utilização de método didático pela Faculdade de Ciências Biológicas envolvendo animais, método esse que não vinha sendo utilizado pela Universidade até então; que a autonomia didático-científica das universidades, e, portanto, o direito à educação não são absolutos, encontrando limites, na situação em comento, na liberdade de pensamento e no direito de todos ao meio ambiente ecologicamente equilibrado; e que a Universidade, titular do direito de ensino superior, e com poder de exercê-lo com autonomia didático-científica, excedeu os limites de seu direito, e o que determina a Constituição Federal a respeito da liberdade e dignidade da pessoa (do aluno/autor na situação em comento), não por ter negado o pedido de objeção de consciência do autor, mas pela forma como o fez, subjetivando a matéria em debate, minimizando o pedido do aluno e questionando sua competência e aptidão para cursar a Faculdade de Ciências Biológicas e formar-se biólogo, opinando pela parcial procedência da ação. ${ }^{76}$

Verifica-se que o entendimento do Ministério Público Federal põe-se em harmonia com o entendimento do magistrado de primeira instância, demonstrando uma preocupação não só com a liberdade de consciência do autor, bem como com o tratamento sério que deve ser dispensado à questão ambiental, como direitos fundamentais que são.

A ré apelou, fundamentando que a prática de vivissecção é permitida em todo o território nacional, de acordo com legislação específica e que a decisão afronta o princípio da isonomia, o que foi acolhido pelo TRF4, lavrando o acórdão cuja ementa a seguir será transcrita em que reformou a decisão de primeiro grau:

76 Parecer Ministerial constante dos autos do processo no 2007.71.00.0198820/RS. Deixa-se de citar o nome do Procurador que subscreveu o parecer supracitado uma vez que, não se teve acesso aos autos físicos e, do material disponível no sítio eletrônico do TRF4 não há indicação sobre o nome do Procurador que subscreveu o parecer. 
CURSO DE CIÊNCIAS BIOLÓGICAS. PARTICIPAÇÃO EM AULAS PRÁTICAS COM USO DE ANIMAIS. OBJEÇÃO DE CONSCIÊNCIA. Não é razoável que, no curso de ciências biológicas, deva a Universidade dispensar tratamento diferenciado aos acadêmicos que possuírem objeção de consciência no curso em que matriculados, e adaptar o currículo de acordo com as convicções pessoais dos alunos, sob pena de inviabilizar a instituição de ensino, sobretudo, quando não há notícias de abuso na utilização de animais para uso acadêmico, apenas e tão-só a obrigação legal do ensino, da pesquisa e formação competente do profissional egresso das classes de universidades conceituadas como a recorrente. (TRF4, APELREEX 2007.71.00.019882-0, QUARTA TURMA, Relator JORGE ANTONIO MAURIQUE, D.E. 05/11/2010).

Posteriormente o aluno interpôs Recurso extraordinário, o qual teve seguimento negado em razão de suposta falta de préquestionamento da matéria constitucional, tendo o autor agravado da decisão denegatória de seguimento do recurso, sem êxito. Ao final do processo, a presente ação foi julgada com a perda do objeto, e, ainda que a decisão tenha sido desfavorável, o autor já havia concluído o curso e alcançado o objetivo primeiro.

Embora a oposição de objeção de consciência em casos de práticas que utilizem animais não seja comum, por motivo de desconhecimento dessa possibilidade, ou mesmo por pressão das instituições e dos professores, e até mesmo dos próprios colegas, observa-se outro caso em que foi utilizado o instituto, como se verifica em ação ajuizada em face da Universidade Federal do Rio de Janeiro, no processo no 2009.02.01.009861-5/RJ, que tramitou na $11^{\text {a }}$ Vara Federal do Rio de Janeiro.

Uma aluna ajuizou ação ordinária com pedido de antecipação de tutela contra a Universidade Federal do Rio de Janeiro, requerendo sua inscrição na disciplina de ZOO III e em disciplinas 
supervenientes, sendo assegurada a dispensa das aulas práticas que façam uso de animais, utilizando métodos alternativos para fins de aprovação. A instituição ré contestou alegando que as práticas com utilização de animais são permitidas por lei e que somente os maus-tratos são vedados. Após sentença que julgou improcedente a demanda, tendo como fundamentação somente a legislação e a jurisprudência do caso ocorrido no Rio Grande do Sul, aqui já referido, a autora não interpôs recurso e o feito transitou em julgado.

Com efeito, sequer se pode falar em jurisprudência consolidada sobre o tema, eis que durante a pesquisa somente foram encontradas duas demandas, aqui já citadas, por conseguinte é preciso alterar o paradigma que afeta cientistas, professores e pesquisadores de se manter fiéis a práticas ultrapassadas, mas também é imprescindível levar essas discussões ao poder judiciário até que se construa um entendimento uniforme sobre a questão proposta sem descuidar da combatividade necessária em busca de uma mudança efetiva nessa prática tão nociva.

\section{CONSIDERAÇÕES FINAIS}

Diante da análise feita neste trabalho, extrai-se a conclusão de que a objeção de consciência, embora reconhecida como um direito fundamental legítimo pela doutrina, ainda não tem sua utilização reconhecida em decisões judiciais transitado em julgado para a defesa da consciência daquele que o invoca em face das atividades de ensino que utilizam animais.

Contudo, na medida em que se verifica o fundamento para essa oposição em razões ligadas à ética animal, constata-se também a possibilidade de utilização desse instituto como objetivo de garantir o direito àquele indivíduo que tem sua consciência violada pela imposição de uma prática educacional que acarrete, na sua perspectiva valorativa, um desrespeito, uma violência moral ou física, uma crueldade ou mesmo a morte a um animal senciente. 
Indiretamente, assim, o reconhecimento do direito fundamental à objeção de consciência no âmbito das atividades de ensino que utilizam animais, também acarreta uma proteção aos animais, na medida em que promove no âmbito acadêmico uma reflexão sobre as práticas de utilização animal e a necessidade de busca por métodos alternativos para tais práticas, mesmo diante da carência de efetividade da legislação da própria norma constitucional que veda crueldade aos animais.

Ademais esse direito se fundamenta na dignidade da pessoa humana e tem por escopo tutelar a consciência da pessoa, evitando o sentimento causado pela violação às suas convicções morais e a repercussão que pode provocar na esfera íntima, pois se trata de um direito individual.

Assim como bem demonstrado no trabalho, além de garantir proteção às objeções que se encontram expressas na legislação e trazidas pela doutrina, comprova-se ser extensível a novas possibilidades de oposição, como na hipótese estudada, contra as atividades que utilizem animais no ensino. Com efeito, cabe ressaltar que a questão ética de que trata o trabalho, se presta não só para fundamentar a oposição de objeção de consciência como também demonstra fundamento para a erradicação das práticas de ensino que realizam experimentos em animais.

Defende-se, pois, com base na senciência animal e no princípio da igual consideração de interesses, que os animais não-humanos são sujeitos-de-uma-vida e merecem consideração moral assim como os humanos. Entende-se como maior obstáculo o antropocentrismo que há séculos vem legitimando o comportamento humano de exploração sobre os animais não-humanos, com a ideia de que estes estão aqui tão somente para servir. Enquanto essa ideia de exploração não for erradicada do pensamento e entendimento do ser humano, haverá um animal não-humano sendo vítima desse sistema, com a legitimação do direito.

Isso revela que vivemos um direito que ainda é conservador e apegado a dogmas passados, uma vez que resiste à reflexão de que o homem não é o centro do mundo, havendo uma urgente 
necessidade de se amoldar às transformações sociais, sob pena de se fazer injusto e excludente.

Destarte, a legislação estudada possui força normativa, todavia carece de efetividade plena tanto na garantia dos direitos conferidos aos animais quanto na garantia dos direitos dos indivíduos de se manifestarem contra qualquer ato que venha a ferir suas convicções. Contudo, não é o que se depreende das decisões dos tribunais.

Primeiramente por razões de diversas ordens as pessoas não chegam a ajuizar ações exigindo seu direito de não realizar algo que vá contra sua vontade, e, por conseguinte, a visão dogmática e ultrapassada dos magistrados que decidem de forma legalista, sem fazer uma análise das questões mais profundas que envolvem esse tipo de discussão, acaba por não efetivar um direito fundamental, como é o caso da objeção de consciência, por questões meramente de costume, ou pela visão antropocêntrica que legitima tal tratamento dispensado aos animais e que de forma direta atinge a própria tutela de um direito fundamental do indivíduo.

Quanto aos julgados analisados, as instâncias superiores não têm a sensibilidade e percepção de conferir consideração moral aos animais, eis que compartilham do senso comum da sociedade, de que os animais estão a serviço e para servir o ser humano, traduzindo-se, ainda, o especismo seletivo, em que somente alguns, como por exemplo, animais domésticos (cães e gatos) merecem tal consideração.

Conclui-se, portanto, que a objeção de consciência, mesmo sendo um direito fundamental pautado na dignidade da pessoa humana, quando invocado em face de atividades de ensino que utilizam animais, não recebe a importância devida, justamente pela visão antropocêntrica que corrobora a ideia de que os animais são objetos e aqui estão apenas para servir ao homem, olvidando as decisões judiciais, que o que está em jogo, no caso, é o direito não de um animal, mas de um ser humano, o qual faz 
uso da objeção de consciência para manter hígidas suas convicções morais, éticas e filosóficas.

\section{REFERÊNCIAS BIBLIOGRÁFICAS}

ACKEL FILHO, Diomar. Direitos dos Animais. São Paulo: Themis, 2001, p. 61-63.

ALBUQUERQUE, Lia do Valle C. de. A ética e a experimentação animal à luz do direito brasileiro e da União Europeia. Revista Brasileira de Direito Animal. V. 10, n. 18, jan-abr. 2015, p. 96-97.

BARROSO, Luis Roberto. A dignidade da pessoa humana no direito constitucional contemporâneo: a construção de um conceito jurídico à luz da jurisprudência mundial / Luis Roberto Barroso; tradução Humberto Laport de Mello - 3 reimpressão. - Belo Horizonte: Fórum, 2014, p. 15.

BARROSO, Luis Roberto. Curso de Direito Constitucional Contemporâneo: os conceitos fundamentais e a construção do novo modelo. 2 ed. Rio de Janeiro: Editora Saraiva, 2010, p. 78.

BERNARDES, Juliano Taveira; FERREIRA, Olavo Augusto Vianna Alves. Direito Constitucional - TOMO II - Direito Constitucional Positivo. Coordenação Leonardo de Medeiros Garcia. 5a ed. rev. ampl. e atual. Ediatora JusPODVIM, p. 33.

BRASIL. Constituição da República Federativa do Brasil de 1988. Disponível em: <http://www.planalto.gov.br/ccivil_03/constituicao/ constituicaocompilado.htm> Acesso em: 11 nov. 2018.

BRASIL. Constituição dos Estados Unidos do Brasil de 1937. Disponível em: <http://www.planalto.gov.br/ccivil_03/Constituicao/Constituicao37.htm> Acesso em: 16 nov. 2018.

BRASIL. Constituição dos Estados Unidos do Brasil de 1946. Disponível em: <http://www.planalto.gov.br/ccivil_03/Constituicao/Constituicao46.htm> Acesso em: 16 nov. 2018.

BRASIL, Constituição Política do Império do Brazil. Disponível em: <http://www.planalto.gov.br/ccivil_03/Constituicao/Constituicao24. htm> Acesso em: 16 nov. 2018.

BRASIL. Decreto-Lei no 2.848, de 7 de dezembro de 1940. Código Penal. Disponível em: <http://www.planalto.gov.br/ccivil_03/decreto-lei/ Del2848compilado.htm> Acesso em: 11 nov. 2018. 
BRASIL. Decreto-Lei no 3.688, de 03 de outubro de 1941. Lei das Contravenções Penais. Disponível em: <http://www.planalto.gov.br/ ccivil_03/Decreto-Lei/Del3688.htm> Acesso em: 11 nov. 2018.

BRASIL. Decreto no 9.175, de 18 de outubro de 2017. Lex: Regulamenta a Lei 9.434, de 04 de fevereiro de 1997, para tratar da disposição de órgãos, tecidos, células e parte do corpo humano para fins de transplante e tratamento. Disponível em: <http://www.planalto.gov.br/ ccivil_03/_ato2015-2018/2017/decreto/D9175.htm> Acesso em: 11 nov. 2018.

BRASIL. Lei no 6.638, de 08 de maio de 1979. Lex: Estabelece normas para a prática didático-científica da vivissecção de animais e determina outras providências. Revogada pela Lei 11.794, de 08 de outubro de 2008. Disponível em:<http://www.planalto.gov.br/ccivil_03/_ato20072010/2008/lei/l11794.htm> Acesso em: 11 nov. 2018.

BRASIL. Lei no 9.434, de 04 de fevereiro de1997. Lex: Dispõe sobre a emoção de órgãos, tecidos e partes do corpo humano para fins de transplante e tratamento e dá outras providências. Disponível em: <http://www.planalto.gov.br/ccivil_03/leis/L9434.htm> Acesso em: 11 nov. 2018.

BRASIL. Lei no 9.605, de 12 de fevereiro de 1998. Lex: Dispõe sobre as sanções penais e administrativas derivadas de condutas e atividades lesivas ao meio ambiente, e dá outras providências. Disponível em: http://www.planalto.gov.br/ccivil_03/LEIS/L9605.htm Acesso em: 11 nov. 2018.

BRASIL. Lei no 11.794 de 08 de outubro de 2008. Lex: Regulamenta o inciso VII do $\S 1^{\circ}$ do artigo 225 da Constituição Federal, estabelecendo procedimentos para o uso científico de animais; revoga a Lei no 6.638, de 08 de maio de 1979; e dá outras providências. Disponível em: < http://www.planalto.gov.br/ccivil_03/_ato2007-2010/2008/lei/l11794. htm> Acesso em: 11 nov. 2018.

BRASIL. MINISTÉRIO DA CIÊNCIA, TECNOLOGIA E INOVAÇÃO, CONCEA. Diretriz brasileira para o cuidado e a utilização de animais para fins científicos e didáticos - DBCA. Brasília/DF. 2013, p. 10. Disponível em: <http://pages.cnpem.br/ceua/wp-content/uploads/ sites/56/2015/06/DBCA.pdf> Acesso em: 10 nov. 2018.

BRASIL. Ministério da Ciência, Tecnologia, Inovações e Comunicações. Conselho Nacional de Controle de Experimentação Animal - CONCEA. Disponível em: <https://www.mctic.gov.br/mctic/opencms/ 
institucional/concea/paginas/concea.html> Acesso em: 02 set. 2018. BRASIL. 9a Vara Federal de Porto Alegre. Lex: Sentença 0066/2007. Róber Freitas Bachinski e Universidade Federal do Rio Grande do Sul. Juiz Candido Alfredo Silva Leal Junior. Porto Alegre, 26 de maio 2008. Disponível em: <https://www2.trf4.jus.br/trf4/processos/visualizar_documento_gedpro.php?local=jfrs\&documento $=3312740 \&$ DocComposto $=\&$ Sequencia $=\&$ hash $=5 \mathrm{bba} 4665 \mathrm{e} 7 \mathrm{fb} 831406 \mathrm{ec} 56975 \mathrm{cfe} 58 \mathrm{db}>$ Acesso em: 11 nov. 2018.

BUZANELLO, José Carlos. Objeção de consciência: uma questão constitucional. Revista de Informação Legislativa. Brasília a. 38 n. 152 out/dez 2001. Disponível em: <https://www2.senado.leg.br/bdsf/ bitstream/handle/id/730/r152-13.pdf?sequence=4> Acesso em: 01 fev. 2018, p. 173-182.

CONSELHO FEDERAL DE MEDICINA VETERINÁRIA. Define e caracteriza crueldade, abuso e maus-tratos contra animais vertebrados, dispõe sobre a conduta de médicos veterinários e zootecnistas e dá outras providências. Resolução no 1.236, de 26 de outubro de 2018. Diário Oficial da União, Brasília, DF, Edição 208, Seção 1. Disponível em: <http:// portal.imprensanacional.gov.br/web/guest/materia/-/asset_publisher/ Kujrw0TZC2Mb/content/id/47542721/do1-2018-10-29-resolucao-n1-236-de-26-de-outubro-de-2018> Acesso em: 11 nov. 2018, p. 133.

DARWIN, Charles; LORENZ, Konrad. A expressão das Emoções no Homem e nos Animais. São Paulo: Companhia das Letras, 2000, p. 73.

DECLARAÇÃO UNIVERSAL DOS DIREITOS HUMANOS. Assembleia Geral das Nações Unidas em Paris. 10 dez. 1948. Disponível em: <https:// nacoesunidas.org/direitoshumanos/declaracao/> Acesso em: 16 nov. 2018.

DIAS, Edna Cardozo. A defesa dos animais e as conquistas legislativas do movimento de proteção animal no Brasil. Revista Brasileira de Direito Animal. Vol. 2. N. 2. Jan/jun, 2007, p. 160.

Dicionário de Política / Norberto Bobbio, Nicola Matteuci e Gianfranco Pasquino; tradução Carmen C. Varriale... [et. Al.]; coordenação da tradução João Ferreira; revisão geral João Ferreira e Luís Guerreiro Pinto Cascais. 5a ed. - Brasília: Editora Universidade de Brasília: São Paulo: Imprensa Oficial do Estado de São Paulo, 2000, p. 335.

DINIZ, Débora. Objeção de Consciência. Disponível em: <http://www. 
anis.org.br/objecao-de-consciencia/> Acesso em: 02 set. 2018.

FEIJÓ, Anamaria Gonçalves dos Santos. Utilização de animais na investigação e docência: uma reflexão ética necessária. Porto Alegre: EDIPUCRS, 2005, p. 73.

FELIPE, Sônia Terezinha. Ética e experimentação animal: fundamentos abolicionistas. Florianópolis: Editora da UFSC, 2007, p. 28.

Francis Crick Memorial Conference. Cambridge, UK, july $7^{\text {th }} 2012$. Declaração de Cambridge sobre Consciência em Animais Humanos e Não Humanos. Disponível em: <fcmconference.org/> Acesso em: 24/10/2018.

GREFF, André Luiz Carvalho; GARABINI, Vânia Maria Basílio. Desobediência Civil e objeção de consciência: distinções. Revista da Faculdade de Direito da UFRGS, Porto Alegre, n. 36, vol. esp. 2017. Disponível em: <http://www.seer.ufrgs.br/index.php/revfacdir/article/ view/69927/44457> Acesso em: 02 set. 2018, p. 177.

GREIF, Sérgio. Alternativas ao uso de animais vivos na educação pela ciência responsável. São Paulo: Instituto Nina Rosa, 2003, p. 15-32.

GREIF, Sergio; TRÉZ, Thales. A Verdadeira Face da Experimentação Animal. Rio de Janeiro: Sociedade Educacional Fala Bicho, 2000. Disponível em: <http://www.falabicho.org.br/PDF/LivroFalaBicho.pdf> Acesso em: 24 out. 2018, p. 13.

KANT, Immanuel. Metafísica dos Costumes. Tradução [primeira parte] Célia Aparecida Martins, tradução [segunda parte] Bruno Nadai, Diego Kosbiau e Monique Hulshof. Petrópolis, RJ: Vozes; Bragança Paulista, SP: Editora Universitária São Francisco, 2013. (Coleção Pensamento Humano). Disponível em: <http://lelivros.love/book/baixar-livro-fundamentacao-da-metafisica-dos-costumes-immanuel-kant-em-pdf-epub-emobi-ou-ler-online/> Acesso em: 20 out. 2018, p. 28.

LIMA, João Epifânio Regis. Vozes do Silêncio: cultura científica: ideologia e alienação no discurso sobre vivissecção. 1ํㅡㄹ. ed. São Paulo: Instituto Nina Rosa, 2008, p. 20.

MEDEIROS, Fernanda Luiza Fontoura de; ALBUQUERQUE, Letícia. Constituição e animais não-humanos: um impacto no direito contemporâneo. Disponível em: <http://www.publicadireito.com.br/artigos/?cod=1845faa2957cb42b> Acesso em: 11 nov. 2018, n.p.

MELLO, Cleyson de Moraes. Direitos Fundamentais e Dignidade da 
Pessoa Humana / Cleyson de Moraes Mello, Thiago Moreira. - Rio de Janeiro: Freitas Bastos, 2015. Disponível em: <https://bv4.digitalpages. com.br/?term=cleyson $\% 2520$ moraes $\% 2520 \mathrm{de} \% 2520$ mello\&searchpage $=1 \&$ filtro $=$ todos $\&$ from $=$ busca $\&$ page $=235 \&$ section $=0 \# /$ edicao $/ 37882>$ Acesso em: 02 out. 2018, p. 207.

Métodos de pesquisa / [organizado por] Tatiana Engel Gerhardt e Denise Tolfo Silveira; coordenado pela Universidade Aberta do Brasil - UAB/UFRGS e pelo Curso de Graduação Tecnológica - Planejamento e Gestão para o Desenvolvimento Rural da SEAD/UFRGS. Porto Alegre: Editora da UFRGS, 2009, p. 32.

NACONECY, Carlos Michelon. Ética \& animais: um guia de argumentação filosófica. Porto Alegre: Edipucrs, 2006, p. 17-19.

PAZZINI, Bianca. Direitos animais e literatura. Rio de Janeiro: Lumen Juris, 2017, p. 94.

PINHO, Rodrigo César Rebello. Teria Geral da Constituição e direitos fundamentais. 12a ed. vol. 17. São Paulo: Saraiva, 2012, p. 200.

REGAN, Tom. Jaulas Vazias: encarando o desafio dos direitos animais; tradução Regina Rheda; revisão técnica Sônia Felipe, Rita Paixão. Porto Alegre: Lugano, 2006, p. 65-72.

RAMMÊ, Rogério Santos. Especismo e esquizofrenia moral na tutela jurisdicional do crime de maus-tratos a animais: uma mirada jurisprudencial. In: SCHEFFER, Gisele Kronhardt (org). Direito animal e ciências criminais. Porto Alegre: Canal Ciências Criminais, 2018, p. 124.

REGO, Maria Laura Pinheiro. Análise da Concepção Funcionalista da Estratificação Social. Disponível em: <http://www.repositorio.ufc.br/ bitstream/riufc/4569/1/1972_art_MLPRego.pdf> Acesso em: 18 nov. 2018, p. 04.

RODRIGUES, Nina Trícia Disconzi; FERRARI, Adriane de Freitas. 0 direito à objeção de consciência à experimentação animal em práticas didáticas. Revista Brasileira de Direitos Fundamentais \& Justiça. V. 8. N. 26, 2014. Disponível em: http://dfj.emnuvens.com.br/dfj/article/ view/227 Acesso em: 05 dez. 2018, p. 160-187.

RUSSEL, William M. S.; BURCH, Rex L. The Principles of Humane Experimental Technique. Johns Hopkins Bloomberg School of Public Health. Special Edition. Disponível em: <http://altweb.jhsph.edu/pubs/ books/humane_exp/het-toc> Acesso em: 10 nov. 2018. 
SARLET, Ingo Wolfgang. A Eficácia dos Direitos Fundamentais: uma teoria geral dos direitos fundamentais na perspectiva constitucional. 11 ed. rev. e atual. Porto Alegre: Livraria do Advogado, 2012, p. 38.

SARLET, Ingo Wolfgang. Dignidade da pessoa humana e direitos fundamentais na Constituição Federal de 1988. $8^{a}$ ed. rev. atual. e ampl. Porto Alegre: Livraria do Advogado Editora, 2010, p. 87, 98.

SILVA, Rodrigo Muniz da. Experimentação Animal: Objeção ao Sacrifício do Outro. 2010. 265 f. Dissertação (Mestrado) - Faculdade de Medicina da Universidade de Porto. Porto, 2010.

SILVA, José Afonso da. Curso de Direito Constitucional Positivo. 25 a ed. rev. atual. nos termos da Reforma Constitucional. São Paulo: Editora Malheiros, 2005, p. 191.

SINGER, Peter. Ética Prática. Tradução de Jefferson Luís Camargo. 3 a ed. São Paulo: Martins Fontes, 1998, p. 09-32.

THOREAU, Henry David. A desobediência civil. Tradução de José Geraldo Couto. Editora Companhia das Letras, 2012, p. 06.

TRAJANO, Tagore. Teoria da Constituição: Direito Animal e Pós-Humanismo (Constitutional Theory: Animal Law and Post-Humanism). 2013. Disponível em: <http://www.egov.ufsc.br/portal/sites/default/ files/2013_10_11683_11731.pdf> Acesso em: 02 set. 2018, p. 27.

ZAMORA, Paula López. Análisis comparativo entre La desobediencia civil y La objeción de conciencia. Disponível em: <https://revistas. ucm.es/index.php/ANDH/article/viewFile/ANDH0202110317A/20968> Acesso em: 02 set. 2018, p. 323-334. 